University of Nebraska - Lincoln

DigitalCommons@University of Nebraska - Lincoln

\title{
Biomarkers of metals exposure in fish from lead-zinc mining areas of Southeastern Missouri, USA
}

Christopher J. Schmitt

U.S. Geological Survey, cjschmitt@usgs.gov

Jeffrey J. Whyte

ASci Corporation

Aaron P. Roberts

Miami University - Oxford, aproberts@unt.edu

Mandy L. Annis

US Geological Survey, mannis@usgs.gov

Thomas W. May

US Geological Survey, tmay@usgs.gov

See next page for additional authors

Follow this and additional works at: https://digitalcommons.unl.edu/usgsstaffpub

Schmitt, Christopher J.; Whyte, Jeffrey J.; Roberts, Aaron P.; Annis, Mandy L.; May, Thomas W.; and Tillitt, Donald E., "Biomarkers of metals exposure in fish from lead-zinc mining areas of Southeastern Missouri, USA" (2007). USGS Staff -- Published Research. 565.

https://digitalcommons.unl.edu/usgsstaffpub/565

This Article is brought to you for free and open access by the US Geological Survey at DigitalCommons@University of Nebraska - Lincoln. It has been accepted for inclusion in USGS Staff -- Published Research by an authorized administrator of DigitalCommons@University of Nebraska - Lincoln. 


\section{Authors}

Christopher J. Schmitt, Jeffrey J. Whyte, Aaron P. Roberts, Mandy L. Annis, Thomas W. May, and Donald E. Tillitt 


\title{
Biomarkers of metals exposure in fish from lead-zinc mining areas of Southeastern Missouri, USA
}

\author{
Christopher J. Schmitt ${ }^{\mathrm{a}, *}$, Jeffrey J. Whyte ${ }^{\mathrm{b}, 1}$, Aaron P. Roberts ${ }^{\mathrm{c}, 2}$, Mandy L. Annis ${ }^{\mathrm{a}}$, \\ Thomas W. May ${ }^{\mathrm{a}}$, Donald E. Tillitt ${ }^{\mathrm{a}}$ \\ ${ }^{a}$ US Geological Survey (USGS), Columbia Environmental Research Center (CERC), 4200 New Haven Rd., Columbia, Missouri 65201, USA \\ ${ }^{\mathrm{b}}$ ASci Corporation, c/o USGS-CERC \\ ${ }^{\mathrm{c}}$ Department of Zoology, Miami University, Oxford, Ohio 45056, USA
}

Received 19 April 2006; received in revised form 22 November 2006; accepted 17 December 2006

Available online 1 March 2007

\begin{abstract}
The potential effects of proposed lead-zinc mining in an ecologically sensitive area were assessed by studying a nearby mining district that has been exploited for about $30 \mathrm{y}$ under contemporary environmental regulations and with modern technology. Blood and liver samples representing fish of three species (largescale stoneroller, Campostoma oligolepis, $n=91$; longear sunfish, Lepomis megalotis, $n=105$; and northern hog sucker, Hypentelium nigricans, $n=20$ ) from 16 sites representing a range of conditions relative to mining activities were collected. Samples were analyzed for metals (also reported in a companion paper) and for biomarkers of metals exposure [erythrocyte $\delta$-aminolevulinic acid dehydratase (ALA-D) activity; concentrations of zinc protoporphyrin (ZPP), iron, and hemoglobin $(\mathrm{Hb})$ in blood; and hepatic metallothionein (MT) gene expression and lipid peroxidation]. Blood lead concentrations were significantly higher and ALA-D activity significantly lower in all species at sites nearest to active lead-zinc mines and in a stream contaminated by historical mining than at reference or downstream sites. ALA-D activity was also negatively correlated with blood lead concentrations in all three species but not with other metals. Iron and $\mathrm{Hb}$ concentrations were positively correlated in all three species, but were not correlated with any other metals in blood or liver in any species. MT gene expression was positively correlated with liver zinc concentrations, but neither MT nor lipid peroxidase differences among fish grouped according to lead concentrations were statistically significant. ZPP was not detected by hematofluorometry in most fish, but fish with detectable ZPP were from sites affected by mining. Collectively, these results confirm that metals are released to streams from active lead-zinc mining sites and are accumulated by fish.

(C) 2007 Elsevier Inc. All rights reserved.
\end{abstract}

Keywords: $\delta$-aminolevulinic acid dehydratase activity; Lead; Cadmium; Zinc; Cobalt; Nickel; Hemoglobin; Zinc protoporphyrin; Metallothionein; Lipid peroxidation

\section{Introduction}

The extensive lead $(\mathrm{Pb})$ deposits of southern Missouri were first discovered by early French explorers of the Mississippi River valley. Subsequently discovered ores

\footnotetext{
*Corresponding author.

E-mail address: cjschmitt@usgs.gov (C.J. Schmitt).

${ }^{1}$ Present address: Department of Biomedical Sciences, Christopher S. Bond Life Sciences Center, University of Missouri-Columbia, Columbia, Missouri 65211, USA.

${ }^{2}$ Present address: Department of Biological Sciences \& Institute of Applied Sciences, University of North Texas, P.O. Box 310559, Denton, TX 76203, USA.
}

containing variable amounts of $\mathrm{Pb}$, zinc $(\mathrm{Zn})$, copper $(\mathrm{Cu})$, cadmium $(\mathrm{Cd})$, cobalt $(\mathrm{Co})$, nickel $(\mathrm{Ni})$, silver, and other metals have been mined at varying levels of intensity for more than $300 \mathrm{y}$. Mining currently occurs only in the "New Lead Belt" (NLB), which exploits a geologic formation known as Viburnum Trend. In contrast to previous large-scale $\mathrm{Pb}-\mathrm{Zn}$ mining, the NLB was developed during the 1960s and has operated under environmental regulations and with the most efficient extraction technologies available (Jennett and Callier, 1977; Wixson and Jennett, 1975; Wixson, 1978). By the 1980s, two decades of exploitation had depleted the Viburnum Trend and mining activity in the NLB declined. Continuing 
exploration revealed additional potentially exploitable deposits southwest of the Viburnum Trend, within the boundaries of the Mark Twain National Forest. This area is in an environmentally sensitive part of southern Missouri that hosts recreationally significant aquatic resources including springs, caves, natural areas, a National Park, and a Federally designated Scenic River that could be threatened by mining. In response to public concerns, a multi-year interdisciplinary investigation was initiated to evaluate potential environmental consequences of expanded $\mathrm{Pb}-\mathrm{Zn}$ mining in the exploration area (Imes, 2002). The study described here, which represents part of the larger investigation, was focused in the NLB as a model for the potential consequences of expanded mining elsewhere in southern Missouri.

The primary objective of our study was to document metals concentrations and biomarkers of metals exposure in fish from streams representing a wide range of conditions related to contemporary $\mathrm{Pb}-\mathrm{Zn}$ mining in the Missouri Ozarks. This was achieved by collecting blood and liver samples of fish from the exploration area and other reference areas and from sites located at various distances from NLB mines, analyzing them for metals and biomarkers of metals exposure, and comparing the results to pertinent data from the scientific literature. Secondary objectives included the refinement of biomarker methods for use with small fish and the documentation of metals concentrations and biomarker responses in a species for which they had not been evaluated previously. The use of small fish was necessary because many NLB mines and there associated mills and tailings disposal facilities are located near headwater streams that are too small to support large fish in the numbers necessary for metals and biomarker analyses by traditional methods (e.g., Schmitt et al., 1984, 1993). The metals analyses, which are reported in a companion paper (Schmitt et al., 2007), indicated that blood and liver $\mathrm{Pb}$ concentrations were elevated in fish from sites near NLB mines, but that mining-related trends in the concentrations of $\mathrm{Cd}$ and $\mathrm{Zn}$ were less evident. Elevated blood and liver concentrations of $\mathrm{Co}$ and $\mathrm{Ni}$ in fish from one site in the NLB were also reported. In this paper we report the results of the biomarker analyses performed on the fish analyzed for metals by Schmitt et al. (2007).

\section{Methods of study}

\subsection{Study design}

Fish of two species, largescale stoneroller (Campostoma oligolepis; henceforth stoneroller) and longear sunfish (Lepomis megalotis; sunfish), were collected from each site. Northern hog sucker (Hypentelium nigricans; hog sucker), a species collected in previous studies (Schmitt et al., 1984, 1993), were retained for analysis when captured incidentally to facilitate temporal and inter-species comparisons. Sites 1-14, in the Black and Meramec River systems, were selected to represent the range of conditions present in the NLB relative to mining; they included reference sites $(n=3)$ located upstream of all mining activity and sites situated $1.4-49.8 \mathrm{~km}$ downstream of NLB mines and ore processing facilities (Schmitt et al., 2007). Sunfish were not present in the immediate vicinity of
Sites 6 and 14 but were obtained 2-5 km downstream of the other species (Schmitt et al., 2007). A site on the Eleven Point River (Site 15) was selected to represent existing conditions in the exploration area and also served as an additional reference site. The Big River (Site 16), which has been contaminated by mine tailings from historical mining in the Old Lead Belt (e.g., Gale et al., 2004; Schmitt et al., 1984), was also sampled. Sites 2, $5,9,14$, and 16 were sampled for blood metals and biomarkers by previous studies (Dwyer et al., 1988; Schmitt et al., 1984, 1993, 2005) and were used for temporal and inter-species comparisons. All sites were sampled in September 2001 except Site 16, which was sampled in early December 2001. More complete descriptions of the study area and the fish collection sites are presented by Schmitt et al. (2007).

\subsection{Biomarkers}

Oxidative damage in hepatic tissues, which can result from exposure to a variety of metals (Farag et al., 1995), was assessed by measuring fluorescent products of lipid peroxidation (FPLPs). The FPLPs represent the interaction of polyunsaturated fatty acid peroxidation products with phospholipids and amino groups of membrane proteins (Dillard and Tappel, 1984). They tend to be long-lived and remain at the sites of oxidative damage (Mezzetti et al., 1999). The FPLPs react with proteins to alter the structure of membranes and form fluorophores, which were measured fluorometrically (Farag et al., 1995).

Metallothioneins (MTs) are ubiquitous low molecular weight proteins and polypeptides of extremely high metal and sulfur content that are involved in the intracellular fixation and regulation of the essential trace elements $\mathrm{Zn}$ and $\mathrm{Cu}$. They can also mitigate the harmful effects of toxic metals such as $\mathrm{Pb}, \mathrm{Cd}$, and mercury (Kägi and Schäffer, 1988). The induction of MT synthesis, which we quantified by measuring MT mRNA expression with reverse-transcriptase polymerase chain reaction (RT-PCR), represents a sensitive biomarker of metals exposure (Tom et al., 2004).

The biochemical effects of $\mathrm{Pb}$ were evaluated at several points in the heme biosynthetic pathway; we measured the activity of the enzyme $\delta$-aminolevulinic acid dehydratase (ALA-D; EC 4.2.1.24) and concentrations of hemoglobin $(\mathrm{Hb})$, iron $(\mathrm{Fe})$, and zinc protoporphyrin (ZPP) in blood. The condensation of two molecules of $\delta$-aminolevulinic acid (ALA) to one molecule of porphobilinogen (PBG), which is catalyzed by ALA-D, occurs early in the heme biosynthetic pathway. Lead inhibits ALA-D stoichiometrically (Chisolm et al., 1985; Kelada et al., 2001) by displacing $\mathrm{Zn}$ at the metal binding site (Warren et al., 1998), which inhibits the enzyme by changing its quaternary structure. Erythrocyte ALA-D inhibition is a well documented biomarker of $\mathrm{Pb}$ exposure in many vertebrates, including humans (e.g., Blus et al., 1991; Goldstein et al., 1975; Hodson, 1976; Schmitt et al., 2005). The terminal step in the heme biosynthetic pathway is the insertion of $\mathrm{Fe}^{2+}$ into protoporphyrin IX, which is catalyzed by the mitochondrial enzyme heme synthetase (ferrochelatase, EC 4.99.1.1; Joselow, 1980). Ferrochelatase inhibition causes the accumulation of protoporphyrin IX, which may also result from Pb-impaired Fe delivery or utilization (Joselow, 1980; Labbé et al., 1999; Sakai, 2000). Protoporphyrin IX chelates free $\mathrm{Zn}^{2+}$ to become zinc protoporphyrin (ZPP), which can be measured by hematofluorometry (Labbé et al., 1999; Lee et al., 2001; Gurer-Orhan et al., 2004). Although widely used in human medicine, the measurement of ZPP and other porphyrins as a consequence of $\mathrm{Pb}$ exposure in fish has received little study (e.g., Hodson et al., 1984; Theodakoris et al., 1992). Heme homeostasis can also be affected by other metals present in the ores of the NLB, including $\mathrm{Cd}, \mathrm{Ni}, \mathrm{Cu}$, and Co (e.g., Maines, 1980; Maines and Sinclair, 1977; Taylor, 1990).

\subsection{ZPP pilot studies}

We conducted pilot studies with laboratory-raised fish of several species to determine whether ZPP could be measured by hematofluorometry and to optimize field and laboratory procedures. In the first study (Study 1), ZPP was measured in preserved erythrocytes of common carp (Cyprinus 
carpio, $n=3$ ) and bluegill (Lepomis macrochirus, $n=6)$. Blood $(1-3 \mathrm{~mL})$ was obtained by caudal veinipuncture with a heparinized $(6 \mathrm{IU} / \mu \mathrm{L})$ needle and syringe and transferred immediately to chilled heparinized Vacutainers ${ }^{\circledR}$ (BD Diagnostics, Franklin Lakes, NJ), chilled on ice, then refrigerated $\left(4^{\circ} \mathrm{C}\right)$. Erythrocytes were preserved within $8 \mathrm{~h}$ as follows: samples were centrifuged for $2 \mathrm{~min} @ 3500 \mathrm{rpm}$, the supernatants were aspirated, and a 1:1 volume of saline solution $(9 \mathrm{~g} / \mathrm{L} \mathrm{NaCl})$ was added. The erythrocytes were re-suspended by gentle rocking and the procedure was repeated three times. After aspiration of the final saline wash, an equal volume of $40 \%$ glycerol solution in citrate buffer was added. The preserved samples were analyzed with three different hematofluorometers to evaluate consistency among instruments.

In the second study (Study 2), whole blood (1-3 mL) was obtained as described from bluegill $(n=10)$ and lake sturgeon (Acipenser oxyrynchus, $n=16)$, transferred to heparinized Vacutainers, and refrigerated $\left(4^{\circ} \mathrm{C}\right)$. Samples were analyzed by hematofluorometry over $7 \mathrm{~d}$ to evaluate the effects of storage time.

\subsection{Field procedures}

Most fish were collected by DC electrofishing and by seining. Sunfish were also collected by hook-and-line. The collection target was six (each) adult stoneroller (75-150 mm total length, 3-20 g) and juvenile sunfish (100-150 mm, 30-60 g) samples at each site. Hog sucker were larger $(100-150 \mathrm{~mm}, 40-650 \mathrm{~g})$. Most fish were analyzed individually; however, because the sunfish and stoneroller at several sites were small, some were analyzed as composites with a "sample" representing the number of fish (typically 1-3) necessary to provide approximately $400 \mu \mathrm{L}$ of blood. All fish were held alive in plastic containers filled with aerated stream water for $\leqslant 2 \mathrm{~h}$ following capture.

Blood was collected from stoneroller and sunfish with a chilled $\left(0{ }^{\circ} \mathrm{C}\right)$, heparinized microcapillary tube $(75 \mu \mathrm{L}$ for stoneroller and small sunfish, $370 \mu \mathrm{L}$ for larger sunfish) after severing the caudal peduncle with a razor blade. Blood was obtained from hog sucker by caudal veinipuncture using a heparinized $(6 \mathrm{IU} / \mathrm{mL})$ needle and syringe. The blood was dispensed immediately into a chilled $2-\mathrm{mL}$ cryogenic tube from which $200 \mu \mathrm{L}$ was transferred with a heparinized microcapillary tube to a pre-weighed, acidcleaned $10-\mathrm{mL}$ borosilicate glass tube with a Teflon ${ }^{\circledR}$ cap, which was then frozen immediately in dry ice for metals analysis (including Fe). One drop was next dispensed onto each of two clean pieces of Parafilm $\mathbf{M}^{\mathbb{R}}$ (American National Can, Menasha, WI) and analyzed immediately for $\mathrm{Hb}$ with a HemoCue ${ }^{\circledR}$ (HemoCue AB, Ängelholm, Sweden) portable blood photometer (Schmitt et al., 2005). Replicate field measurements of $\mathrm{Hb}$ were consistent in all three species; coefficients of variation (CVs) were $\leqslant 10 \%$ in 89 of $105(85 \%)$ sunfish, 88 of $94(94 \%)$ stoneroller, and 19 of 20 $(95 \%)$ hog sucker. $\mathrm{Hb}$ is therefore reported as the mean of the two observations for each sample $(\mathrm{g} / \mathrm{dL})$.

The remaining blood was dispensed into a $5-\mathrm{mL}$ cryogenic vial and chilled $\left(0^{\circ} \mathrm{C}\right.$, for ZPP and ALA-D analysis). Following blood collection the fish was euthanized by cervical dislocation, measured (total length, $\mathrm{mm}$ ), and weighed (g). The abdominal cavity was opened by dissection and a liver sample (ca. $0.5 \mathrm{~g}$ ) was obtained and divided into three approximately equal sub-samples for metals and biomarker analyses. These samples were placed in acid-cleaned $0.5-\mathrm{mL}$ cryogenic vials and frozen immediately in dry ice. All contact surfaces and dissecting instruments were thoroughly cleaned with laboratory detergent, deionized $\mathrm{H}_{2} \mathrm{O}$, and acetone between samples. At the end of each day the chilled blood samples were assayed for ZPP, then frozen immediately in dry ice. Upon return from the field the metals samples were stored frozen at $-20^{\circ} \mathrm{C}$ and the biomarker samples at $-80^{\circ} \mathrm{C}$ until analyzed.

\subsection{Laboratory methods}

\subsubsection{Erythrocyte zinc protoporphyrin (ZPP)}

ZPP in whole blood and preserved erythrocytes was measured directly in units of $\mu \mathrm{mol} \mathrm{ZPP} / \mathrm{mol}$ heme $(\mu \mathrm{mol} / \mathrm{mol})$ based on fluorescence $(415 \mathrm{~nm}$ excitation, $596 \mathrm{~nm}$ emission) using one of several Aviv Model 206D hematofluorometers (Aviv Instrument, Lakewood, NJ). The instruments were calibrated at the beginning and end of each measurement session using procedures and reference materials obtained from the manufacturer (Aviv Biomedical, 2001). One drop $(20 \mu \mathrm{L})$ of whole blood or preserved erythrocytes was placed on a glass coverslip $\left(25 \mathrm{~mm}^{2}\right)$ with a clean polyethylene pipette tip and stirred vigorously for $10 \mathrm{~s}$. ZPP was measured 3-6 times at 60 -s intervals, with $10 \mathrm{~s}$ of stirring between measurements. Duplicate coverslips were prepared and read from at least $10 \%$ of each group of samples; the unweighted mean for each fish is reported. The limit of detection (LOD) was $5.0 \times 10^{-12} \mathrm{~g}$ ZPP per drop of blood (nominally $1 \mu \mathrm{mol} / \mathrm{mol}$; Aviv Biomedical, 2001).

\subsubsection{ALA-D activity}

Erythrocyte ALA-D activity in $25-\mu \mathrm{L}$ subsamples of homogenized whole blood was assayed in 96-well microtiter plates as described by Schmitt et al. (2005). Each sample was analyzed in triplicate; the arithmetic mean of the three observations is reported. For quality control (QC) purposes one triplicate sample per plate was randomly selected for duplicate analysis in a separate location on the plate. Concentrations of $\mathrm{Hb}$ in each well were also measured with the HemoCue as described previously. Enzyme activity in each well was computed as nmol PBG $/ \mu \mathrm{L}$ blood/h using the sample absorbance reading and the parameters (slope and y-intercept) from the regression of the PBG standard curve. Mean ALA-D activity was also standardized to both field- and laboratorydetermined $\mathrm{Hb}$ concentrations and reported as nmol $\mathrm{PBG} / \mathrm{mg} \mathrm{Hb} / \mathrm{h}$. The LODs and limits of quantitation (LOQs) for the method were calculated as described by Keith et al. (1983) using the daily assay method blanks. The LODs and LOQs were consistent among plates; the mean LOD was $0.043 \pm 0.001$ (SD) absorbance units and the mean LOQ was $0.053 \pm 0.002$ absorbance units. The ALA-D measurements were also very repeatable; $>95 \%$ of the triplicate (well) measurements made on each sample had CVs of $<20 \%$, and duplicate samples had CVs of $<10 \%$ in all three species.

\subsubsection{Hepatic lipid peroxidation}

A total of 30 liver samples (15 each stoneroller and sunfish) were analyzed for FPLPs with a fluorometric assay modified from Farag et al. (1995) and Dillard and Tappel (1984). Five fish of each species representing "low", "medium", and "high" blood $\mathrm{Pb}$ concentrations were selected (low $=0.02-0.07 \mu \mathrm{g} / \mathrm{g} \mathrm{dw}$ in sunfish, $0.02-0.05 \mu \mathrm{g} / \mathrm{g} \mathrm{dw}$ in stoneroller, from Sites 3, 10 , and 15 ; medium $=0.25-0.44 \mu \mathrm{g} / \mathrm{g} \mathrm{dw}$ in sunfish, $0.15-0.26 \mu \mathrm{g} / \mathrm{g} \mathrm{dw}$ in stoneroller, from Sites 1, 5, and 6; high $=1.42-3.80 \mu \mathrm{g} / \mathrm{g} \mathrm{dw}$ in sunfish, $1.65-3.30 \mu \mathrm{g} / \mathrm{g} \mathrm{dw}$ in stoneroller, from Sites 14 and 16). Approximately $200 \mathrm{mg}$ of frozen liver tissue from each fish was homogenized in $0.5 \mathrm{~mL}$ of ice-cold $\mathrm{dH}_{2} \mathrm{O}$ at medium speed for $15 \mathrm{~s}$ in an Omni tissue homogenizer (Omni International, Marietta, GA). The homogenate and a $0.5 \mathrm{~mL}$ ice-cold $\mathrm{dH}_{2} \mathrm{O}$ rinse were transferred to a $15-\mathrm{mL}$ glass centrifuge tube, $2 \mathrm{~mL}$ of 2:1 chloroform:methanol were added, and the mixture was vortexed for $1 \mathrm{~min}$. Ice-cold $\mathrm{dH}_{2} \mathrm{O}(1 \mathrm{~mL})$ was then added and the sample was vortexed and centrifuged $(2 \mathrm{~min}$ at $1200 \times \mathrm{g})$. Chloroform was removed, $100 \mu \mathrm{L}$ of methanol was added, and the sample was again vortexed. Samples were irradiated at $250 \mathrm{~nm}$ in a UV light box for $5 \mathrm{~min}$ to remove the fluorescence contribution of compounds such as retinol. Aliquots $(200-\mu \mathrm{L})$ of each sample were analyzed in triplicate in 96well plates (360 nm excitation; $460 \mathrm{~nm}$ emission) with a Cytofluor ${ }^{\circledR}$ Model 2300 (Millipore, Billerica, MA). A quinine sulfate standard curve was prepared $(0.000-0.002 \mu \mathrm{g} / \mathrm{mL}$ quinine sulfate) for each set of samples for standardization of relative fluorescence values per unit of tissue mass. The error associated with the slope of the routine quinine sulfate standard curves was $<1 \%$ and $\mathrm{CV}$ s for procedural blanks averaged $\leqslant 5 \%$ for the duration of the study. The LODs and LOQs for the method, calculated as described for ALA-D, were consistent among plates; the mean LOD was $37.5 \pm 2.27$ (SD) fluorescence units, and the mean LOQ was $44.9 \pm 5.72$ fluorescence units. Hepatic lipid peroxidation, as indicated by relative fluorescence, exceeded the method LOD and LOQ in all samples analyzed, and $>97 \%$ of the triplicate (wells) measurements made on each sample had an associated $\mathrm{CV}$ of $<5 \%$. 


\subsubsection{Metallothionein (MT) expression}

Hepatic MT mRNA was measured in stoneroller liver samples from a reference site (Site 10, Sinking Creek; $n=6$ ) and Site 16 (Big River, $n=6$ ). Samples were analyzed by RT-PCR using the methods of McClain et al. (2003) and Roberts and Oris (2004) with DNA primers synthesized from fathead minnow (Pimephales promelas). Total oligonucleotide was isolated by acid guanidinium thiocyanate phenol-chloroform extraction using Tri-Reagent (Sigma, St. Louis, MO, USA; manufacturer's protocol) and was quantified spectrophotometrically at $260 \mathrm{~nm}$. Reverse transcription was carried out using the First-Strand cDNA Synthesis Kit (Amersham Pharmacia, Uppsala, Sweden). The PCR reactions contained $25 \mu \mathrm{L}$ total volume $[5 \mu \mathrm{L}$ of reverse transcription product, $2.5 \mu \mathrm{L}$ of $10 \mathrm{X}$ PCR Buffer, $1 \mu \mathrm{L}$ of $5 \mathrm{mM}$ DNTPs, $0.5 \mu \mathrm{L}$ of $15 \mu \mathrm{M}$ oligonucleotide primer, $1 \mu \mathrm{L}$ of Taq polymerase (2.5 units), and $15 \mu \mathrm{L}$ of DNAase-free water]. Amplification occurred over 24 cycles $\left(94^{\circ} \mathrm{C}\right.$ for $30 \mathrm{~s}, 55.5^{\circ} \mathrm{C}$ for $30 \mathrm{~s}$, and $72^{\circ} \mathrm{C}$ for $30 \mathrm{~s})$. Amplification products were electrophoresed in 1.5\% LE Agarose (Fisher Biotech, Fairlawn, NJ) and stained with ethidium bromide for visualization and quantitation using Gel-Pro Analyzer software (Media Cybernetics, Silver Spring, MD). The optical density of each sample's MT band was obtained and standardized on a sample-by-sample basis to the optical density of an 18S rRNA band using commercially available primers (Ambion, Austin, TX). The ratio of MT optical density to $18 \mathrm{~S}$ optical density was used as a measure of relative gene expression.

\subsubsection{Blood moisture content and Fe}

Frozen blood samples were freeze-dried, digested with $\mathrm{HNO}_{3}$ and $\mathrm{H}_{2} \mathrm{O}_{2}$, and analyzed for Fe by inductively coupled plasma mass spectrometry (ICPMS) as described by Schmitt et al. (2005, 2007). Moisture content was determined from weight loss during lyophilization. Iron was analyzed and reported as both dry-weight (dw) and wet-weight (ww) concentrations, the latter computed from the moisture content of each sample. The LODs for $\mathrm{Fe}$, calculated assuming a digestion weight of $50 \mathrm{mg}$ of dry blood, were $1.0-40 \mu \mathrm{g} / \mathrm{g} \mathrm{dw}$.

\subsection{Data set composition and statistical analyses}

Release 9.1 of the Statistical Analysis System (SAS Institute, Cary, NC) was used for all statistical analyses. A total of 219 samples were included in the univariate analyses; 94 samples representing all 16 stations were stoneroller (only one sample was obtained from Site 7), 105 samples from 16 sites were sunfish, and 20 samples from Sites 4, 7, 8, 11-13, and 16 were hog sucker. Several samples could not be analyzed for Hb or ALA-D due to clotting, and three sunfish samples representing Sites 1 and 5 were excluded from regression and correlation analyses because of suspiciously high blood or liver $\mathrm{Zn}$ concentrations indicative of possible external contamination (Schmitt et al., 2007). Both $\mathrm{dw}$ and ww blood $\mathrm{Fe}$ concentrations were analyzed for differences among sites and species, but only the ww concentrations were used in correlation and regression analyses because of the association of $\mathrm{Fe}$ with $\mathrm{Hb}$, the latter determined in the field on whole blood. Censored values $(<\mathrm{LOD})$ were replaced with $50 \%$ of the LOD for statistical computations and graphing, and all data representing elemental and $\mathrm{Hb}$ concentrations and ALA-D activity were $\log _{10}$-transformed prior to statistical analysis. Individual variables were analyzed statistically using analysis-of-covariance (ANCOVA) and analysis-of-variance (ANOVA). In these analyses, differences among sites were tested within each species with Fisher's protected LSD test. Sites were also grouped according to their distance from mining (Schmitt et al., 2007): "reference" (no upstream mining-Sites 3, 10, 11, and 15); "near mine" ( $<10 \mathrm{~km}$ downstream from an NLB mine-Sites $2,4,6,7,12$, and 14); and "downstream" ( $>10 \mathrm{~km}$ downstream from an NLB mine-Sites 1, $5,8,9$, and 13). Differences among groups of sites were tested as planned non-orthogonal contrasts using single degree-of-freedom $F$-tests. Results of the ZPP pilot studies were analyzed by ANCOVA and mixed-model ANOVA to evaluate the effects of fish species, instruments, individual fish, replicate samples, and storage time on ZPP concentrations. The biomarker data reported here were combined with the metals data reported by Schmitt et al. (2007) and examined statistically with Pearson correlation coefficients, simple linear (least-squares) regression, and stepwise multiple linear regression. In the latter, the forward selection method was used and variables were allowed into the models only if they significantly $(P<0.05)$ reduced the unexplained sum-of-squares after accounting for all other factors already included (i.e., the Type-II sums-of-squares were used). Molar concentrations of $\mathrm{Hb}([\mathrm{Hb}])$ and $\mathrm{Fe}([\mathrm{Fe}])$ in blood were computed on the basis of the approximate molecular weight of common carp $\mathrm{Hb}$ (65.88 kD; Grujic-Injac et al., 1980) and the atomic weight of Fe (55.85) and analyzed using simple linear regression and geometric mean (functional) regression (Ricker, 1973).

\section{Results}

Blood $\mathrm{Pb}$ concentrations were significantly greater in fish of all three species from sites located downstream of mines than at reference sites (Table 1). Concentrations in all three species were greatest at Site 16 (Big River) and at sites located nearest to NLB mines (Table 1). Concentrations of $\mathrm{Pb}$ in blood and liver were highly correlated in all three species (Schmitt et al., 2007). Concentrations of $\mathrm{Cd}$ in blood and liver also differed significantly among sites, but mining-related trends were less apparent than for $\mathrm{Pb}$, and $\mathrm{Zn}$ differences were even less apparent (Schmitt et al., 2007). The biomarker results reflected the differing metals concentrations.

\subsection{ALA-D activity}

Among-species differences in un-standardized ALA-D activity were not statistically significant $(P>0.05)$ when considered across all sites, nor were differences in ALA-D activity standardized to either field- or laboratory-measured $\mathrm{Hb}$ (ALA-D/Hb; data not shown). However, significant

Table 1

Activity of the enzyme $\delta$-aminolevulinic acid dehydratase [ALA-D, nm porphobilinogen (PBG)/mL blood/h], ALA-D activity normalized to laboratorydetermined hemoglobin $(\mathrm{Hb})$ concentrations $(\mathrm{nm} \mathrm{PBG} / \mathrm{mg} \mathrm{Hb} / \mathrm{h}$ ), field-measured $\mathrm{Hb}$ concentrations $(\mathrm{g} / \mathrm{dL})$, and concentrations of lead $(\mathrm{Pb}, \mu \mathrm{g} / \mathrm{g}$ dry weight) and iron (Fe, $\mu \mathrm{g} / \mathrm{g}$ wet weight) in the blood of three fish species

\begin{tabular}{|c|c|c|c|c|c|c|}
\hline Species, site, and type ${ }^{\mathrm{a}}$ & $n / \mathrm{df}$ & Blood $\mathrm{Pb}$ & ALA-D & ALA-D/Hb & $\mathrm{Hb}$ & Blood Fe \\
\hline \multicolumn{7}{|l|}{ Hog sucker ${ }^{\mathrm{b}}$} \\
\hline 4 (Bee Fork; M) & 2 & $2.14 \pm 0.82 \mathrm{~b}$ & $1.7 \pm 0.1 \mathrm{a}$ & $2.6 \pm 0.4 \mathrm{cde}$ & $9.1 \pm 0.5 \mathrm{a}$ & $293 \pm 3$ a \\
\hline $12($ Strother Creek; M) & 3 & $1.37 \pm 0.10 \mathrm{~b}$ & $1.3 \pm 0.2 \mathrm{a}$ & $2.4 \pm 0.1 \mathrm{ed}$ & $7.4 \pm 0.2 \mathrm{a}$ & $217 \pm 7 a b$ \\
\hline 8 (Black R. @ Lesterville; D) & 4 & $0.20 \pm<0.01 \mathrm{c}$ & $1.3 \pm 0.1 \mathrm{a}$ & $2.9 \pm 0.3 \mathrm{bcd}$ & $8.8 \pm 1.0 \mathrm{a}$ & $250 \pm 34 \mathrm{a}$ \\
\hline 13 (Neals Creek; D) & 3 & $0.36 \pm 0.03 \mathrm{c}$ & $1.5 \pm 0.2 \mathrm{a}$ & $3.4 \pm 0.2 \mathrm{ab}$ & $7.7 \pm 0.8 \mathrm{a}$ & $232 \pm 16 a b$ \\
\hline
\end{tabular}


Table 1 (continued)

\begin{tabular}{|c|c|c|c|c|c|c|}
\hline Species, site, and type ${ }^{a}$ & $n / \mathrm{df}$ & Blood $\mathrm{Pb}$ & ALA-D & $\mathrm{ALA}-\mathrm{D} / \mathrm{Hb}$ & $\mathrm{Hb}$ & Blood Fe \\
\hline 11 (Middle Fork@Redmondville; R) & 3 & $0.28 \pm 0.04 \mathrm{c}$ & $1.8 \pm 0.3 \mathrm{a}$ & $3.4 \pm 0.1 \mathrm{abc}$ & $8.3 \pm 0.5 \mathrm{a}$ & $241 \pm 14 \mathrm{a}$ \\
\hline 16 (Big R.) & 3 & $6.63 \pm 0.87 \mathrm{a}$ & $0.6 \pm 0.2 \mathrm{~b}$ & $2.2 \pm 0.1 \mathrm{e}$ & $4.1 \pm 1.3 \mathrm{~b}$ & $125 \pm 37 \mathrm{c}$ \\
\hline ANOVA- $F$ & $6,13^{\mathrm{c}}$ & $44.00 * *$ & $4.73 * *$ & $5.70 * *$ & $2.98 *$ & $3.43 *$ \\
\hline$R^{2}$ & 20 & 0.95 & 0.69 & 0.72 & 0.58 & 0.61 \\
\hline \multicolumn{7}{|l|}{ Sunfish ${ }^{\mathrm{d}}$} \\
\hline 2 (West Fork@West Fork; M) & 10 & $0.44 \pm 0.05 \mathrm{c}$ & $0.9 \pm 0.1 \mathrm{f} \mathrm{fg}$ & $2.0 \pm 0.2 \mathrm{~g}$ & $7.1 \pm 0.4 \mathrm{abcd}$ & $172 \pm 9$ abcde \\
\hline 4 (Bee Fork; M) & 8 & $1.13 \pm 0.90 \mathrm{~b}$ & $0.8 \pm 0.1 \mathrm{~g}$ & $1.9 \pm 0.1 \mathrm{~g}$ & $6.2 \pm 0.3 \mathrm{def}$ & $175 \pm 9$ abcde \\
\hline 6 (Logan Creek@Corridon; M) & 6 & $0.32 \pm 0.04 \mathrm{de}$ & $1.4 \pm 0.1 \mathrm{abc}$ & $3.1 \pm 0.1 \mathrm{bc}$ & $7.6 \pm 0.2 \mathrm{a}$ & $167 \pm 9$ cde \\
\hline 7 (Sweetwater Creek; M) & 6 & $1.32 \pm 0.30 \mathrm{~b}$ & $1.1 \pm 0.1 \mathrm{cdef}$ & $2.5 \pm 0.2 \mathrm{def}$ & $7.5 \pm 0.4 \mathrm{ab}$ & $165 \pm 17 \mathrm{de}$ \\
\hline 12 (Strother Creek; M) & 6 & $0.62 \pm 0.14 \mathrm{c}$ & $0.8 \pm 0.1 \mathrm{fg}$ & $2.3 \pm 0.3 \mathrm{efg}$ & $5.2 \pm 0.3 \mathrm{~g}$ & $157 \pm 8 \mathrm{de}$ \\
\hline 14 (Courtois Creek; M) & 6 & $0.64 \pm 0.19 \mathrm{cf}$ & $1.0 \pm 0.1 \mathrm{efg}$ & $2.7 \pm 0.2 \mathrm{cde}$ & $6.1 \pm 0.3 \mathrm{def}$ & $178 \pm 7$ abcd \\
\hline 1 (Black R.@Sutton Bluff; D) & 7 & $0.16 \pm 0.02 \mathrm{f}$ & $0.9 \pm 0.1 \mathrm{efg}$ & $2.0 \pm 0.1 \mathrm{fg}$ & $6.2 \pm 0.2 \mathrm{cdef}$ & $173 \pm 5$ abcde \\
\hline 5 (Logan Creek@Ellington; D) & 6 & $0.39 \pm 0.10 \mathrm{cde}$ & $1.4 \pm 0.2$ abcd & $3.1 \pm 0.2 \mathrm{bcd}$ & $7.2 \pm 0.4 \mathrm{abc}$ & $175 \pm 11$ abcde \\
\hline 8 (Black R. @ Lesterville; D) & 6 & $0.09 \pm 0.10 \mathrm{~g}$ & $1.6 \pm 0.2 \mathrm{abc}$ & $3.5 \pm 0.2 \mathrm{ab}$ & $6.4 \pm 0.3 \mathrm{cde}$ & $197 \pm 3 \mathrm{ab}$ \\
\hline 9 (Middle Fork@Black; D) & 6 & $0.17 \pm 0.03 \mathrm{f}$ & $1.6 \pm 0.1 \mathrm{ab}$ & $3.6 \pm 0.3 \mathrm{ab}$ & $6.0 \pm 0.3$ efg & $172 \pm 11$ abcde \\
\hline 13 (Neals Creek; D) & 6 & $0.18 \pm 0.04 \mathrm{f}$ & $1.1 \pm 0.1 \mathrm{defg}$ & $2.6 \pm 0.3 \mathrm{cdef}$ & $6.2 \pm 0.4$ cdef & $194 \pm 8$ abc \\
\hline 3 (West Fork@Greeley; R) & 6 & $0.09 \pm 0.02 \mathrm{~g}$ & $1.1 \pm 0.2 \mathrm{efg}$ & $2.8 \pm 0.2 \mathrm{cde}$ & $6.0 \pm 0.3 \mathrm{efg}$ & $152 \pm 8$ e \\
\hline 10 (Sinking Creek; R) & 7 & $0.09 \pm 0.03 \mathrm{~g}$ & $1.2 \pm 0.1$ bcde & $2.6 \pm 0.2 \mathrm{cde}$ & $6.5 \pm 0.2$ bcde & $201 \pm 9$ a \\
\hline 11 (Middle Fork@Redmondville; R) & $6^{\mathrm{e}}$ & $0.38 \pm 0.07 \mathrm{cde}$ & $1.0 \pm 0.1 \mathrm{defg}$ & $3.1 \pm 0.4 \mathrm{bcd}$ & $5.4 \pm 0.3 \mathrm{gf}$ & $170 \pm 8$ bcde \\
\hline 15 (Eleven Point R.; R/EA) & 6 & $0.24 \pm 0.04$ ef & $2.0 \pm 0.3 \mathrm{a}$ & $4.0 \pm 0.1 \mathrm{a}$ & $6.3 \pm 0.2 \mathrm{cde}$ & $194 \pm 8$ abc \\
\hline 16 (Big R.) & 7 & $2.65 \pm 0.33 \mathrm{a}$ & $0.8 \pm 0.1 \mathrm{~g}$ & $2.1 \pm 0.2 \mathrm{fg}$ & $5.7 \pm 0.4$ efg & $171 \pm 10$ abcde \\
\hline ANOVA- $F$ & $15,89^{\mathrm{c}, \mathrm{f}}$ & $29.56 * *$ & $6.09 * *$ & $8.34 * *$ & $4.50 * *$ & $1.97 *$ \\
\hline$R^{2}$ & $105^{\mathrm{f}}$ & 0.83 & 0.51 & 0.59 & 0.43 & 0.25 \\
\hline \multicolumn{7}{|l|}{ Stoneroller ${ }^{\mathrm{g}}$} \\
\hline 2 (West Fork@West Fork; M) & 7 & $0.33 \pm 0.02 \mathrm{efg}$ & $1.0 \pm 0.1 \mathrm{bc}$ & $2.0 \pm 0.2 \mathrm{bcd}$ & $8.0 \pm 0.4 \mathrm{abc}$ & $229 \pm 9$ bc \\
\hline 4 (Bee Fork; M) & $6^{\mathrm{h}}$ & $0.98 \pm 0.08 \mathrm{bc}$ & $1.0 \pm 0.1 \mathrm{ab}$ & $1.9 \pm 0.1$ bcde & $8.0 \pm 0.2 \mathrm{ab}$ & $265 \pm 9 \mathrm{ab}$ \\
\hline 6 (Logan Creek@Corridon; M) & $3^{\mathrm{i}}$ & $0.75 \pm 0.11 \mathrm{bcd}$ & $1.0 \pm 0.1 \mathrm{ab}$ & $2.2 \pm 0.1 \mathrm{abcd}$ & $6.6 \pm 0.3 \mathrm{abcd}$ & $223 \pm 11 \mathrm{c}$ \\
\hline 7 (Sweetwater Creek; M) & $1^{\mathrm{j}}$ & $\mathrm{na}^{\mathrm{k}}$ & 0.7 bcde & $1.7 \mathrm{de}$ & $2.3 \mathrm{e}$ & $\mathrm{na}^{\mathrm{k}}$ \\
\hline 12 (Strother Creek; M) & 6 & $0.62 \pm 0.05 \mathrm{~cd}$ & $0.6 \pm 0.2 \mathrm{e}$ & $1.6 \pm 0.3 \mathrm{e}$ & $7.5 \pm 0.2 \mathrm{abc}$ & $219 \pm 11 \mathrm{c}$ \\
\hline 14 (Courtois Creek; M) & $6^{1}$ & $2.25 \pm 0.33 \mathrm{a}$ & $0.6 \pm 0.1 \mathrm{cde}$ & $1.7 \pm 0.1 \mathrm{de}$ & $7.5 \pm 0.5 \mathrm{abc}$ & $220 \pm 11 \mathrm{c}$ \\
\hline 1 (West Fork@Sutton Bluff; D) & 7 & $0.19 \pm 0.01 \mathrm{gh}$ & $1.0 \pm 0.1 \mathrm{ab}$ & $2.3 \pm 0.1 \mathrm{abc}$ & $6.5 \pm 0.2 \mathrm{bcd}$ & $203 \pm 8 c$ \\
\hline 5 (Logan Creek@Ellington; D) & 6 & $0.12 \pm 0.02 \mathrm{ij}$ & $1.7 \pm 0.1 \mathrm{a}$ & $2.8 \pm 0.2 \mathrm{a}$ & $6.7 \pm 0.4$ abcd & $215 \pm 7 \mathrm{c}$ \\
\hline 8 (Black R. @ Lesterville; D) & 6 & $0.15 \pm 0.02 \mathrm{hi}$ & $1.1 \pm 0.1 \mathrm{ab}$ & $1.9 \pm 0.1 \mathrm{cde}$ & $8.0 \pm 0.5 \mathrm{abc}$ & $231 \pm 13 \mathrm{bc}$ \\
\hline 9 (Middle Fork@Black; D) & 6 & $0.30 \pm 0.05 \mathrm{fg}$ & $1.0 \pm 0.2 \mathrm{bcd}$ & $2.2 \pm 0.2 \mathrm{abcd}$ & $5.9 \pm 0.5 \mathrm{~d}$ & $207 \pm 21 \mathrm{c}$ \\
\hline 13 (Neals Creek; D) & 6 & $0.52 \pm 0.06 \mathrm{de}$ & $0.5 \pm 0.1 \mathrm{de}$ & $1.7 \pm 0.1 \mathrm{de}$ & $6.4 \pm 0.5 \mathrm{~cd}$ & $202 \pm 8 \mathrm{c}$ \\
\hline 3 (West Fork@West Fork; R) & 6 & $0.12 \pm 0.04 \mathrm{ij}$ & $1.0 \pm 0.1 \mathrm{~b}$ & $2.2 \pm 0.1 \mathrm{abcd}$ & $7.1 \pm 0.2 \mathrm{abcd}$ & $218 \pm 11 \mathrm{c}$ \\
\hline 10 (Sinking Creek; R) & 7 & $0.03 \pm 0.01 \mathrm{k}$ & $0.9 \pm 0.1 \mathrm{bcd}$ & $2.5 \pm 0.1 \mathrm{ab}$ & $7.8 \pm 0.4 \mathrm{abc}$ & $214 \pm 7 \mathrm{c}$ \\
\hline 11 (Middle Fork@ Redmondville; R) & 6 & $0.35 \pm 0.02$ ef & $0.9 \pm 0.2$ bcde & $2.1 \pm 0.1$ abcd & $7.3 \pm 0.5 \mathrm{abcd}$ & $219 \pm 11 \mathrm{c}$ \\
\hline 15 (Eleven Point R.; R/EA) & 6 & $0.12 \pm 0.05 \mathrm{j}$ & $1.3 \pm 0.3 \mathrm{ab}$ & $2.3 \pm 0.1 \mathrm{abc}$ & $7.8 \pm 0.6 \mathrm{abc}$ & $286 \pm 19$ a \\
\hline 16 (Big R.) & $7^{\mathrm{m}}$ & $1.39 \pm 0.25 \mathrm{ab}$ & $1.1 \pm 0.2 \mathrm{ab}$ & $2.0 \pm 0.3 \mathrm{cde}$ & $8.5 \pm 0.8 \mathrm{a}$ & $270 \pm 12 \mathrm{a}$ \\
\hline ANOVA- $F$ & $15,73^{\mathrm{c}, \mathrm{n}}$ & $37.43 * *$ & $2.94 * *$ & $3.23 * *$ & $4.91 * *$ & $4.10 * *$ \\
\hline$R^{2}$ & $89^{\circ}$ & 0.87 & 0.38 & 0.40 & 0.49 & 0.43 \\
\hline
\end{tabular}

Shown are arithmetic site means $\pm \mathrm{SE}$, number of observations $(n)$, and results of one-way analysis-of-variance (ANOVA) as $F$-values $(* * P<0.01, *$ $P<0.05$, ns $P>0.05$ ), degrees-of-freedom (df), and coefficients of determination $\left(R^{2}\right)$. Within species, means followed by the same letter (ranked alphabetically from highest to lowest) are not significantly different $(P>0.05)$. Blood $\mathrm{Pb}$ data from Schmitt et al. (2007).

${ }^{\mathrm{a}} \mathrm{M},<10 \mathrm{~km}$ downstream of New Lead Belt mine; D, $>10 \mathrm{~km}$ downstream; R, upstream of all mining (reference); EA, exploration area.

${ }^{\mathrm{b}}$ Northern hog sucker, Hypentelium nigricans.

${ }^{\mathrm{c}} \mathrm{df}$.

${ }^{\mathrm{d}}$ Longear sunfish, Lepomis megalotis.

${ }^{\mathrm{e}} n=5$ for ALA-D and ALA-D/Hb.

${ }^{\mathrm{f}} n=104, \mathrm{df}=15,88$ for ALA-D and ALA-D/Hb.

${ }^{\mathrm{g}}$ Largescale stoneroller, Campostoma oligolepis.

${ }^{\mathrm{h}} n=7$ for ALA-D, ALA-D/Hb, and $\mathrm{Hb}$.

${ }^{\mathrm{i}} n=4$ for ALA-D, ALA-D/Hb, and $\mathrm{Hb}$.

${ }^{\mathrm{j}} n=0$ for blood $\mathrm{Pb}$ and $\mathrm{Fe}$; $\mathrm{nd}=$ not determined.

${ }^{\mathrm{k}}$ na $=$ not analyzed.

${ }^{1} n=5$ for ALA-D and ALA-D/Hb.

$\mathrm{m}_{n}=6$ for ALA-D and ALA-D/Hb.

${ }^{\mathrm{n}} \mathrm{df}=15,78$ for $\mathrm{Hb}$ and 14,76 for blood $\mathrm{Pb}$ and $\mathrm{Fe}$.

${ }^{\circ} n=84$ for $\mathrm{Hb}, 91$ for blood $\mathrm{Fe}$. 
species $\times$ site interaction for ALA-D indicated amongspecies differences at some sites. Overall trends for ALA-D activity standardized to field- and laboratory-measured $\mathrm{Hb}$ were similar, but the laboratory-standardized values were slightly less variable. Consequently, ANCOVA explained $69 \%$ of the total variability in the laboratory-standardized values and $66 \%$ in the field-standardized values. We therefore report only the un-standardized (ALA-D) and laboratory $\mathrm{Hb}$-standardized (ALA-D/Hb) values.

Both ALA-D and ALA-D/Hb differed significantly $(P<0.01)$ among sites in all three species (Table 1$)$. In hog sucker, ALA-D was significantly $(P<0.05)$ lower at Site 16 (Big River) than at all others, but the other sites did not differ significantly from each other (Table 1). Amongsite differences in hog sucker were more evident for ALA$\mathrm{D} / \mathrm{Hb}$; Site 16 was lowest, but activity at Site 7 (Sweetwater Creek), which is $2.6 \mathrm{~km}$ downstream from a mine (Schmitt et al., 2007), was among the greatest (Table 1). Consequently, differences between sites $<10 \mathrm{~km}$ downstream from NLB mines, $>10 \mathrm{~km}$ downstream, and reference sites were not significant $(P>0.05)$ in hog sucker, but were significant $(P<0.01)$ in sunfish and stoneroller. In general, and although there were exceptions and overlap within groups of sites, ALA-D activity was typically greatest at reference sites (including Site 15, in the exploration area) and at sites $>10 \mathrm{~km}$ downstream of NLB mines. Conversely, activity was generally lowest at sites near NLB mines and at Site 16 (Big River; Table 1).

ALA-D activity was negatively correlated with blood $\mathrm{Pb}$ in all three species; statistically significant $(P \leqslant 0.01) \log -\log$ linear regressions explained $31 \%$ of the variation in unstandardized ALA-D activity in hog sucker, 7\% in stoneroller, and $13 \%$ in sunfish (Fig. 1). Fish of all three species from sites near NLB mines and the Big River had greater blood $\mathrm{Pb}$ concentrations and less ALA-D activity than those from reference sites and sites $>10 \mathrm{~km}$ downstream from mines, which had lower blood $\mathrm{Pb}$ concentrations and greater ALA-D activity (Fig. 1).

Multiple regression explained a greater percentage of the variation in ALA-D relationships than simple linear regression in all three species. Models that included $\mathrm{Hb}$, either as an independent variable or by incorporating ALA-D $/ \mathrm{Hb}$ as the dependent variable, and other variables such as blood $\mathrm{Zn}$, blood $\mathrm{Cd}$, and blood $\mathrm{Fe}$ in addition to blood $\mathrm{Pb}$ were statistically significant $(P<0.01)$ and explained as much as $96 \%$ of the variation in hog sucker, $51 \%$ in sunfish, and $86 \%$ in stoneroller (Table 2). The models for hog sucker also contained negative terms for total length, indicating a decline in ALA-D activity with fish size (and also increasing blood $\mathrm{Pb}$ ); however, the sample size for hog sucker was small relative to the number of statistically significant terms in the model (Table 2).

\subsection{Blood Fe and hemoglobin}

Concentrations of $\mathrm{Hb}$ were $1.4-11.7 \mathrm{~g} / \mathrm{dL}$ in hog sucker, $4.1-8.8 \mathrm{~g} / \mathrm{dL}$ in sunfish, and $0.8-6.0 \mathrm{~g} / \mathrm{dL}$ in stoneroller.
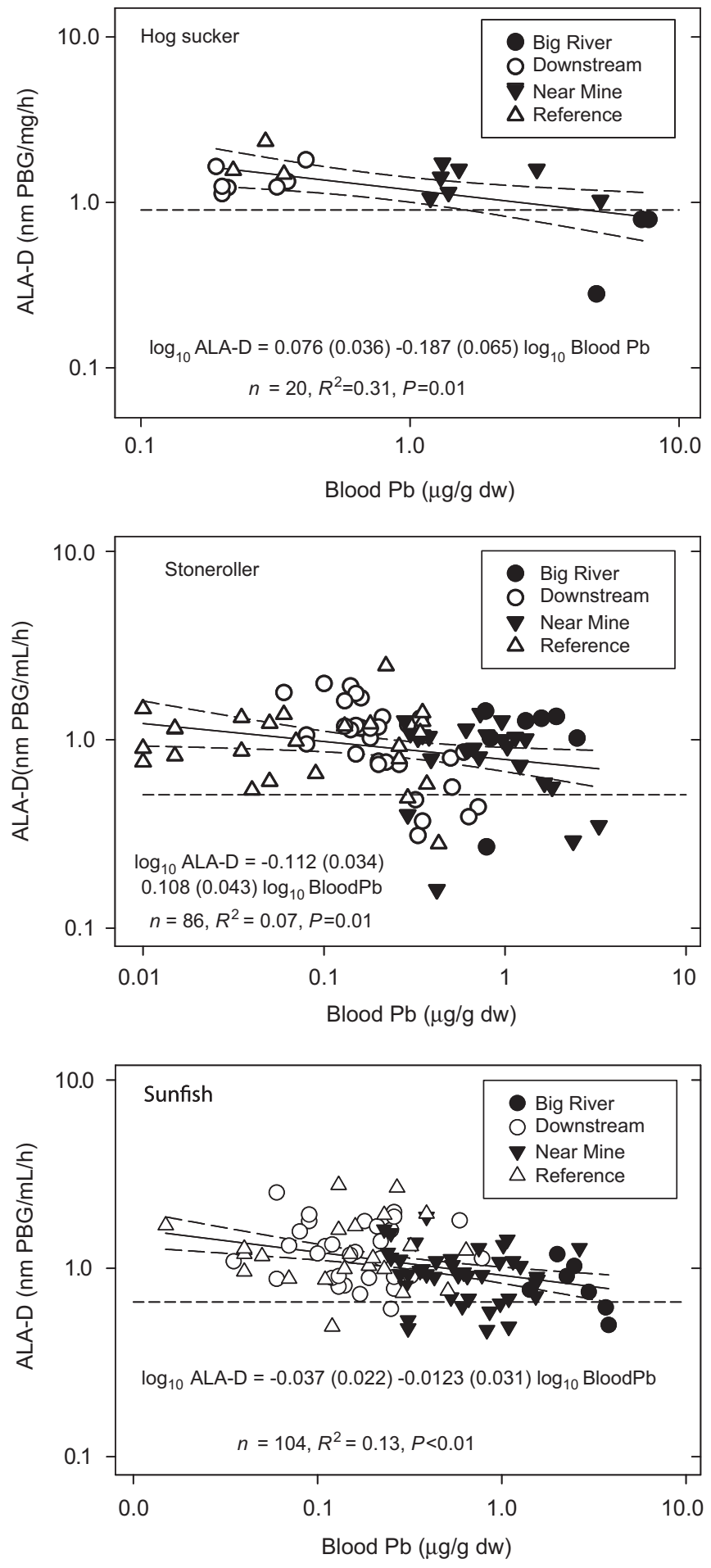

Fig. 1. Activity of $\delta$-aminolevulinic acid dehydratase (ALA-D) and blood lead (Blood Pb, from Schmitt et al., 2007) concentrations in three species of fish from sites $<10 \mathrm{~km}$ downstream from mining-related facilities in the New Lead Belt (Near Mines), $>10 \mathrm{~km}$ downstream (Downstream), no upstream mining (Reference), and the Big River. Also shown for each species are the least-squares regressions (solid lines) and 95\% confidence intervals (long-dashed lines) between these variables across all sites (standard errors in parentheses), and the value representing $50 \%$ of the unweighted mean ALA-D activity at reference sites (short-dashed lines; $0.9 \mathrm{~nm} \mathrm{PBG} / \mathrm{mL} / \mathrm{h}$ for hog sucker, $0.5 \mathrm{nmPBG} / \mathrm{mL} / \mathrm{h}$ for stoneroller, and $0.7 \mathrm{~nm} \mathrm{PBG} / \mathrm{mL} / \mathrm{h}$ for sunfish. 
Table 2

Statistically significant $(* * P<0.01 ; * P<0.05)$ functional and multiple linear regression models describing relations between wet-weight concentrations of hemoglobin as measured in the field $\left(\mathrm{Hb}_{\mathrm{f}}\right)$ and laboratory $\left(\mathrm{Hb}_{\mathrm{l}}\right)$; total length $(\mathrm{TL}, \mathrm{mm})$; concentrations of lead $(\mathrm{Pb})$, cadmium $(\mathrm{Cd})$, zinc $(\mathrm{Zn})$, and iron $(\mathrm{Fe})$ in blood, liver, or both (all $\mu \mathrm{g} / \mathrm{g}$ dry weight; from Schmitt et al., 2007); and activity of the enzyme $\delta$-aminolevulinic acid dehydratase (ALA-D) in the blood of three species of fish, with ALA-D as un-standardized values (nM PBG/mL/h) and standardized to $\mathrm{Hb} \mathrm{f}_{\mathrm{f}}$ and $\mathrm{Hb} \mathrm{l}_{\mathrm{l}}(\mathrm{nM} \mathrm{PBG} / \mathrm{mg} / \mathrm{h}$ )

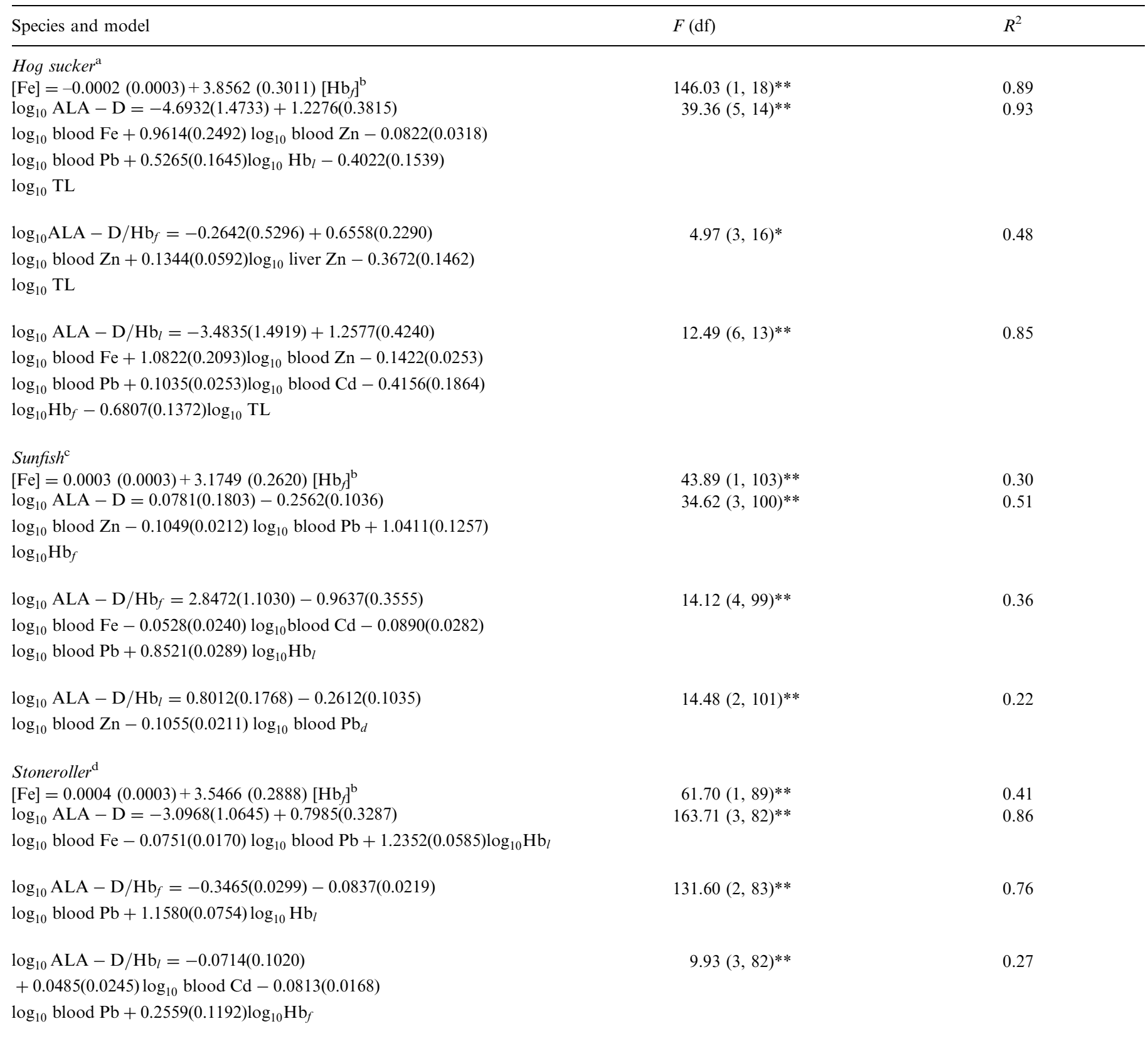

Shown for each model are intercepts and regression coefficients (with standard errors), $F$-values and degrees of freedom (df), and coefficients of determination $\left(R^{2}\right)$.

${ }^{\text {a }}$ Northern hog sucker, Hypentelium nigricans.

${ }^{\mathrm{b}}$ Functional (geometric mean) regression (Ricker, 1973).

${ }^{\mathrm{c}}$ Longear sunfish, Lepomis megalotis.

${ }^{\mathrm{d}}$ Largescale stoneroller, Campostoma oligolepis.

Among-species differences in $\mathrm{Hb}$ concentrations were not statistically significant (ANOVA, $P>0.05$ ), but concentrations were not consistent across all sites, as indicated by significant species $\times$ site interaction $(P<0.05)$. Differences among sites were statistically significant in all three species
(Table 1), but there was considerable variability within sites. Consequently, and although some groups of sites differed significantly from others with respect to mining influence, there were no clearly evident mining-related trends. The lone exceptions were hog sucker from Site 16 
(Big River), in which $\mathrm{Hb}$ concentrations were significantly lower $(P<0.05)$ than at all sites except Site 7 (Sweetwater Creek), which is near an NLB mine (Fig. 2; Table 1).

Blood Fe concentrations (ww and dw) differed significantly $(P<0.01)$ among species; concentrations were typically greater in stoneroller than in hog sucker or sunfish; the species means were $1735 \mu \mathrm{g} / \mathrm{g} \mathrm{dw}(228 \mu \mathrm{g} / \mathrm{g} \mathrm{ww})$ for stoneroller, $1646 \mu \mathrm{g} / \mathrm{g} \mathrm{dw}(215 \mu \mathrm{g} / \mathrm{g} \mathrm{ww})$ for hog sucker, and $1400 \mu \mathrm{g} / \mathrm{g} \mathrm{dw}(177 \mu \mathrm{g} / \mathrm{gww})$ for sunfish. Among-site differences in $\mathrm{dw}$ blood $\mathrm{Fe}$ concentrations were statistically significant $\left(F_{6}, 13=3.49, P<0.05\right)$ in hog sucker but not in sunfish or stoneroller $(F=1.13-1.62, P>0.05)$; however, among-site differences in ww blood $\mathrm{Fe}$ concentrations were significant in all three species (Table 1). Concentrations were $50.1-322 \mu \mathrm{g} / \mathrm{g}$ (ww) in hog sucker, $87.8-230 \mu \mathrm{g} / \mathrm{g}$ in sunfish, and $128-337 \mu \mathrm{g} / \mathrm{g}$ in stoneroller. The results were also similar to those for $\mathrm{Hb}$ in that although blood Fe differences among sites were statistically significant, patterns related to mining influences were not generally evident. The exceptions were low blood Fe concentrations in the same fish from Site 16 and Site 7 identified as having low $\mathrm{Hb}$ relative to other sites (Fig. 2; Table 1).

Concentrations of $\mathrm{Hb}$ and $\mathrm{Fe}$ were positively correlated in all three species. Statistically significant $(P<0.01)$ linear regressions between $[\mathrm{Hb}]$ and $[\mathrm{Fe}]$ with small intercepts and regression coefficients of $1.7-3.6$ explained $89 \%$ of the variation in hog sucker, $41 \%$ in sunfish, and $30 \%$ in stoneroller (Fig. 2). The regression coefficients for the functional regressions, which account for variation in both variables (Ricker, 1973), ranged from 3.1 in sunfish to 4.0 in hog sucker (Table 2). The expected value is 4.0 based on the tetrameric structure of $\mathrm{Hb}$ (Schmitt et al., 2005). Blood Fe concentrations in several stonerollers from sites $<10 \mathrm{~km}$ downstream from mines were lower than expected based on $\mathrm{Hb}$ measurements (Fig. 2), but neither $\mathrm{Hb}$ nor blood $\mathrm{Fe}$ were significantly correlated with blood $\mathrm{Pb}$ in either sunfish or stoneroller $(P>0.05$; data not shown). In contrast, both blood $\mathrm{Fe}$ and $\mathrm{Hb}$ were negatively correlated with blood $\mathrm{Pb}$ in hog sucker $(r=-0.43$ to $-0.57, P<0.05, n=20)$ due to the low $\mathrm{Hb}$ and $\mathrm{Fe}$ concentrations and correspondingly high blood $\mathrm{Pb}$ concentrations in several fish from the Big River (Fig. 2).

\subsection{Zinc protoporphyrin}

\subsubsection{Pilot studies}

Replicate measurements of the samples from Study 1 were consistent; with one exception, all within-fish $\mathrm{CVs}$ were between $0 \%$ and $10 \%$. ANOVA explained $>99 \%$ of the total ZPP variation in preserved common carp and bluegill erythrocytes; differences among fish were significant $\left(F_{8,16}=31.0, P<0.01\right)$ as were those between instruments $\left(F_{2,16}=31.0, P<0.01\right)$ and species $\left(F_{1,16}=5075.3, P<0.01\right)$. Concentrations were $10-23 \mu \mathrm{mol} / \mathrm{mol}$ (mean $=17.9 \mu \mathrm{mol} /$ $\mathrm{mol}$ ) in bluegill and $4-8 \mu \mathrm{mol} / \mathrm{mol}($ mean $=5.7 \mu \mathrm{mol} / \mathrm{mol})$ in common carp (data not shown). Differences among instru-
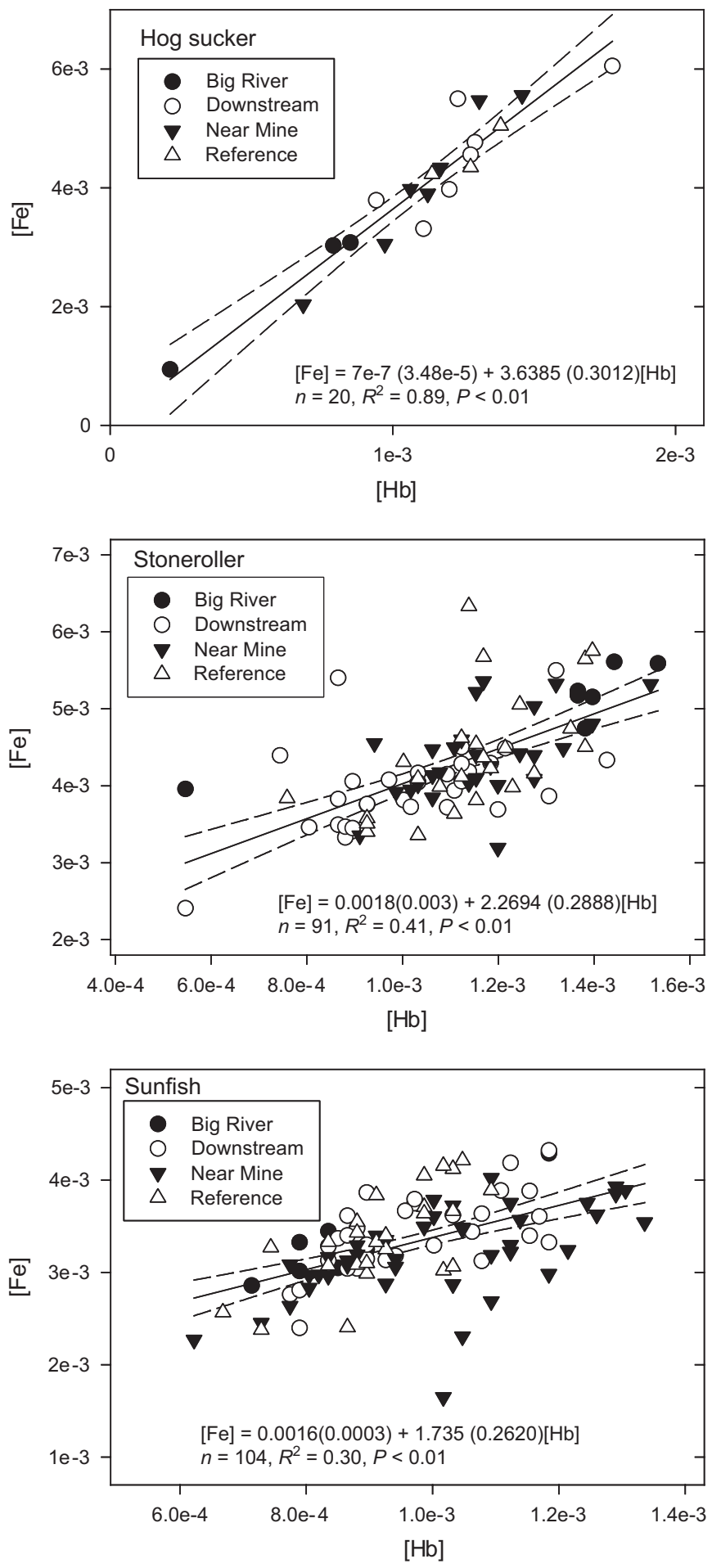

Fig. 2. Molar concentrations of iron $[\mathrm{Fe}]$ and hemoglobin $[\mathrm{Hb}]$ in the blood of three species of fish. Also shown are the linear regressions (solid lines) and 95\% confidence intervals (dashed lines) between these variables across all three species (standard errors in parentheses).

ments were also statistically significant $(P<0.01)$, but the unweighted instrument means $(13.1,13.6$, and $14.6 \mu \mathrm{mol} / \mathrm{mol})$ differed by $<10 \%$ and differences were not consistent among fish, as indicated by significant fish $\times$ instrument interaction $\left(F_{16,26}=2.8, P<0.01\right)$. 
In Study 2, ANOVA also explained $>99 \%$ of the total ZPP variation in whole blood from bluegill and lake sturgeon. Differences between species were significant $\left(F_{1,25}=7433.0, P<0.01\right)$ as were those among individual fish of the same species $\left(F_{22,25}=92.6, P<0.01\right)$, but differences among replicate coverslips from the same fish were not $\left(F_{22,352}=0.8, P>0.05\right.$; data not shown $)$. Day-0 mean concentrations in bluegill were $28.9-53.9 \mu \mathrm{mol} / \mathrm{mol}$ (overall mean $=35.1 \mu \mathrm{mol} / \mathrm{mol}$ ) and $6.6-18.9 \mu \mathrm{mol} / \mathrm{mol}$ (mean $=11.2 \mu \mathrm{mol} / \mathrm{mol})$ in lake sturgeon. Concentrations in the refrigerated samples increased over time in both species; the linear term for days post-collection was significant $\left(F_{2,25}=666.6, P<0.01\right)$, and the rate of increase was greater for bluegill $(8.32 \mu \mathrm{mol} / \mathrm{mol} / \mathrm{d})$ than lake sturgeon $(1.31 \mu \mathrm{mol} / \mathrm{mol} / \mathrm{d})$. As percentages of the Day-0 means, the daily rates of increase were $24 \%$ in bluegill and $12 \%$ in lake sturgeon. Coefficients of variation (based on all measurements of the same fish on a given day) were $2.7-5.7 \%$ in bluegill (mean $=3.9 \%$ ) and $4.3-23.6 \%$ $($ mean $=10.3 \%)$ in lake sturgeon. Collectively, the results of the pilot studies indicated that 3-6 measurements of one coverslip would adequately characterize the ZPP concentration of each fish, but that samples should be analyzed within $24-36 \mathrm{~h}$ of collection. These findings were incorporated into the field protocol.

\subsubsection{Field study}

We detected ZPP in only 26 of 85 stoneroller (31\%) from Sites 9-16; 15 of 104 sunfish (14\%) from Sites 3, 4, 6, 8, 10, 14, and 16; and two of 19 hog sucker (11\%) from Sites 3 and 16 (Fig. 3). Overall, greatest ZPP concentrations were in fish from Site 7 (Logan Creek), Site 8 (Sweetwater Creek), and Site 16 (Big River; Fig. 3). Within-site variability was considerable (Fig. 3), but CVs for individual fish (among measurements) of all three species were generally $<10 \%$. In samples with measurable ZPP, concentrations were $1-71 \mu \mathrm{mol} / \mathrm{mol}$ in sunfish, $2-89 \mu \mathrm{mol} / \mathrm{mol}$ in stoneroller, and $37-135 \mu \mathrm{mol} / \mathrm{mol}$ in hog sucker (Fig. 3). The hog sucker and stoneroller maxima were in samples from Site 16, but the two greatest sunfish concentrations were from Site 8, which is $<10 \mathrm{~km}$ below an NLB mine (Fig. 3). The hog sucker from Site 16 with high ZPP was also among the fish from the Big River with low $\mathrm{Hb}$ and blood Fe concentrations (Fig. 2). The ZPP field data were not analyzed statistically due to the large percentage of censored (i.e., <LOD) values.

\subsection{Hepatic lipid peroxidation}

Blood and liver concentrations of $\mathrm{Pb}$ and $\mathrm{Zn}$ and of $\mathrm{Cd}$ in liver differed significantly between species in the fish selected for FPLP analyses (Table 3). Fish with the highest $\mathrm{Pb}$ concentrations did not necessarily have the highest $\mathrm{Cd}$ or $\mathrm{Zn}$ concentrations. Blood and liver $\mathrm{Pb}$ concentrations also differed significantly $(P<0.01)$ among the groups of fish selected on the basis of $\mathrm{Pb}$ concentrations (low, medium, high) for FPLP analysis. Liver Pb concen-

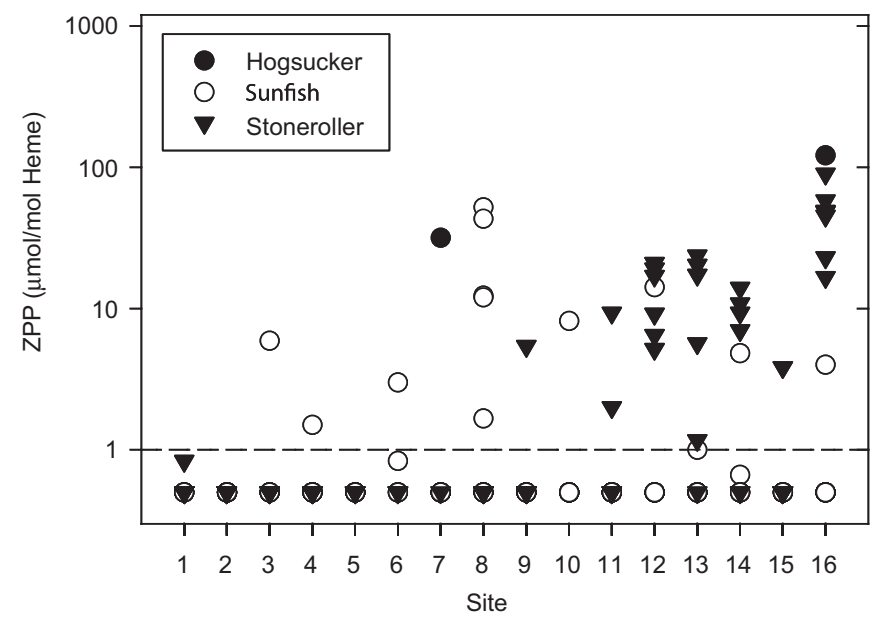

Fig. 3. Concentrations of zinc protoporphyrin (ZPP) in the blood of three species of fish from sites in the New Lead Belt (1-14), the Exploration Area (15), and the Big River (16). The dashed line represents the approximate limit-of-detection $(1.0 \mu \mathrm{mol} / \mathrm{mol}$ heme $)$.

trations were $0.01-3.41 \mu \mathrm{g} / \mathrm{g} \mathrm{dw}$ in individual sunfish and $0.04-7.79 \mu \mathrm{g} / \mathrm{g}$ in stoneroller (Table 3). Blood and liver Cd differences among groups of fish were also significant in both species, but were less evident than those for $\mathrm{Pb}$ (Table 3). Neither blood nor liver $\mathrm{Zn}$ differences were statistically significant in either species $(P>0.05$; Table 3$)$.

Hepatic lipid peroxidation (as FPLPs) differed significantly $(P<0.01)$ between species, with values for stoneroller typically 3 -fold greater than those for sunfish (Table 3). However, differences among high-, medium-, and low- $\mathrm{Pb}$ exposure fish of the same species were not significant $(P>0.05$; Table 3$)$. Correlation and regression analyses also did not detect statistically significant relations between FPLPs and metals concentrations in either blood or liver of individual fish $(P>0.05)$.

\subsection{Metallothionein induction}

Blood and liver $\mathrm{Pb}$ concentrations also differed significantly $(P<0.01)$ between sites in the stoneroller selected for MT analysis by RT-PCR, as did blood Cd concentrations (Table 4). Differences for liver $\mathrm{Cd}$ and $\mathrm{Zn}$ were less evident; they only approached statistical significance $(P=0.09-0.10)$, and mean concentrations of both were greater in fish from Site 10 (Sinking Creek, a reference site) than from Site 16 (Big River; Table 4). Maximum concentrations were $2.98 \mu \mathrm{g} / \mathrm{g} \mathrm{Pb}$ (Site 16), $1.89 \mu \mathrm{g} / \mathrm{g} \mathrm{Cd}$ (Site 10), and $93.3 \mu \mathrm{g} / \mathrm{g} \mathrm{Zn}$ (also Site 10). Estimates of hepatic MT mRNA varied greatly among fish at both sites; CVs were $>50 \%$ and differences between sites were not statistically significant $(P>0.05$; Table 4$)$. Nevertheless, hepatic MT mRNA and liver Zn were positively correlated; a $\log$-log linear regression between these variables was marginally significant $(P=0.06)$ and explained $31 \%$ of the variation in MT mRNA (Fig. 4). No other correlations approached statistical significance. 
Table 3

Arithmetic mean \pm SE concentrations of lead $(\mathrm{Pb})$, cadmium, and zinc in blood and liver (all $\mu \mathrm{g} / \mathrm{g}$ dry-weight, from Schmitt et al., 2007) and fluorescent products of lipid peroxidation (FPLPs, fluorescence standardized to quinaldine sulfate) in liver of fish of two species characterized as being low, medium, or high in blood $\mathrm{Pb}$

\begin{tabular}{|c|c|c|c|c|c|c|c|c|}
\hline \multirow{2}{*}{$\begin{array}{l}\text { Species and } \\
\text { relative } \mathrm{Pb}\end{array}$} & \multirow[t]{2}{*}{$n / \mathrm{df}$} & \multicolumn{3}{|l|}{ Blood } & \multicolumn{4}{|l|}{ Liver } \\
\hline & & Lead & Cadmium & Zinc & Lead & Cadmium & Zinc & FPLPs \\
\hline \multicolumn{9}{|l|}{ Sunfish $^{\mathrm{a}}$} \\
\hline Low & 5 & $0.04 \pm 0.01 \mathrm{a}$ & $0.018 \pm 0.006 \mathrm{a}$ & $55.0 \pm 5.5 \mathrm{a}$ & $0.04 \pm 0.01 \mathrm{a}$ & $1.650 \pm 0.233 \mathrm{a}$ & $91.7 \pm 8.8 \mathrm{a}$ & $1.024 \pm 0.062 \mathrm{a}$ \\
\hline Medium & 5 & $0.32 \pm 0.04 \mathrm{~b}$ & $0.026 \pm 0.015 \mathrm{a}$ & $40.4 \pm 1.7 \mathrm{a}$ & $0.39 \pm 0.10 \mathrm{~b}$ & $4.490 \pm 0.742 \mathrm{~b}$ & $96.2 \pm 3.3 \mathrm{a}$ & $1.016 \pm 0.124 \mathrm{a}$ \\
\hline High & 5 & $2.82 \pm 0.45 \mathrm{c}$ & $0.030 \pm 0.006 \mathrm{a}$ & $54.5 \pm 4.0 \mathrm{a}$ & $1.95 \pm 0.39 \mathrm{c}$ & $11.472 \pm 1.926 \mathrm{c}$ & $66.5 \pm 4.6 \mathrm{a}$ & $1.164 \pm 0.115 \mathrm{a}$ \\
\hline \multicolumn{9}{|l|}{ Stoneroller $^{\mathrm{b}}$} \\
\hline Low & 5 & $0.03 \pm 0.01 \mathrm{a}$ & $0.010 \pm 0.001 \mathrm{a}$ & $49.6 \pm 1.6 \mathrm{a}$ & $0.13 \pm 0.05 \mathrm{a}$ & $0.792 \pm 0.230 \mathrm{a}$ & $93.7 \pm 2.7 \mathrm{a}$ & $3.546 \pm 0.368 \mathrm{a}$ \\
\hline Medium & 5 & $0.19 \pm 0.02 b$ & $0.037 \pm 0.009 \mathrm{~b}$ & $68.5 \pm 2.2 \mathrm{~b}$ & $0.32 \pm 0.10 \mathrm{~b}$ & $1.296 \pm 0.286 \mathrm{~b}$ & $97.2 \pm 9.4 \mathrm{a}$ & $3.196 \pm 0.384 \mathrm{a}$ \\
\hline High & 5 & $2.33 \pm 0.29 \mathrm{c}$ & $0.025 \pm 0.005 \mathrm{a}$ & $62.2 \pm 6.6 \mathrm{a}$ & $5.03 \pm 0.80 \mathrm{c}$ & $3.376 \pm 2.096 \mathrm{c}$ & $116.6 \pm 15.2 \mathrm{a}$ & $3.082 \pm 0.451 \mathrm{a}$ \\
\hline \multicolumn{9}{|l|}{ ANOVA- $F$} \\
\hline Species (S) & $1,24^{\mathrm{c}}$ & $7.05 *$ & $0.19 \mathrm{~ns}$ & $9.74 * *$ & $6.43^{*}$ & $23.41 * *$ & $7.73^{* *}$ & $84.53^{* *}$ \\
\hline $\mathrm{Pb}$ & $2,24^{\mathrm{c}}$ & $376.79^{* *}$ & $4.12 *$ & $1.10 \mathrm{~ns}$ & $7.43^{*}$ & $9.70 * *$ & $0.79 \mathrm{~ns}$ & $0.23 \mathrm{~ns}$ \\
\hline $\mathrm{S} \times \mathrm{Pb}$ & $2,24^{\mathrm{c}}$ & $0.65 \mathrm{~ns}$ & $1.35 \mathrm{~ns}$ & $9.10^{* *}$ & $4.08^{*}$ & $0.67 \mathrm{~ns}$ & $6.50^{* *}$ & $0.53 \mathrm{~ns}$ \\
\hline$R^{2}$ & 30 & 0.97 & 0.32 & 0.56 & 0.90 & 0.65 & 0.48 & 0.78 \\
\hline
\end{tabular}

Also shown are results of two-way analysis-of-variance (ANOVA) as $F$-values $(* * P<0.01 ; * P<0.05$ ), degrees-of-freedom (df), and coefficients of determination $\left(R^{2}\right)$. Within each group of three means, values followed by the same letter are not significantly different $(P>0.05)$.

${ }^{\mathrm{a}}$ Longear sunfish, Lepomis megalotis.

${ }^{\mathrm{b}}$ Largescale stoneroller, Campostoma oligolepis.

${ }^{\mathrm{c}} \mathrm{df}$.

Table 4

Arithmetic mean \pm SE concentrations of lead, cadmium, and zinc in blood and liver (all $\mu \mathrm{g} / \mathrm{g}$ dry-weight, from Schmitt et al., 2007) and metallothionein (MT) induction in liver of largescale stoneroller ${ }^{a}$ from two sites.

\begin{tabular}{|c|c|c|c|c|c|c|c|c|}
\hline \multirow[t]{2}{*}{ Site } & \multirow[t]{2}{*}{$n / \mathrm{df}$} & \multicolumn{3}{|l|}{ Blood } & \multicolumn{4}{|l|}{ Liver } \\
\hline & & Lead & Cadmium & Zinc & Lead & Cadmium & Zinc & MT \\
\hline 10 (Sinking Creek) & 6 & $0.03 \pm 0.01$ & $0.010 \pm 0.001$ & $49.5 \pm 2.5$ & $0.12 \pm 0.04$ & $1.018 \pm 0.237$ & $88.6 \pm 0.2$ & $0.914 \pm 0.190$ \\
\hline 20 (Big River) & 6 & $1.35 \pm 0.29$ & $0.021 \pm 0.004$ & $83.2 \pm 6.5$ & $2.35 \pm 0.21$ & $0.508 \pm 0.077$ & $82.1 \pm 2.8$ & $0.855 \pm 0.184$ \\
\hline ANOVA- $F$ & $1,10^{\mathrm{b}}$ & $190.75^{* *}$ & $14.47 * *$ & $25.52 * *$ & $111.9^{* *}$ & $3.33 \mathrm{~ns}^{\mathrm{c}}$ & $3.50 \mathrm{~ns}^{\mathrm{b}}$ & $0.05 \mathrm{~ns}$ \\
\hline$R^{2}$ & 11 & 0.95 & 0.59 & 0.72 & 0.92 & 0.25 & 0.26 & $<0.01$ \\
\hline
\end{tabular}

Also shown are the results of analysis-of-variance (ANOVA) as $F$-values $(* * P<0.01 ; * P<0.05)$, degrees-of-freedom (df), and coefficients of determination $\left(R^{2}\right)$.

${ }^{\mathrm{a}}$ Campostoma oligolepis.

${ }^{\mathrm{b}} \mathrm{df}$.

${ }^{\mathrm{c}} P=0.09-0.10$

\section{Discussion}

Threshold blood $\mathrm{Pb}$ concentrations associated with effects on heme synthesis in fish, as indicated by reduced ALA-D activity, vary among species. In most species (including hog sucker and sunfish), reduced ALA-D activity has been reported at blood- $\mathrm{Pb}$ concentrations exceeding about $0.5 \mathrm{mg} / \mathrm{L}$ (about $4 \mu \mathrm{g} / \mathrm{gdw}$ assuming $87.5 \%$ moisture), but varying indirectly with $\mathrm{Zn}$ burden (Dwyer et al., 1988; Schmitt et al., 1984, 1993, 2002). In channel catfish (Ictalurus punctatus) the threshold may be only $0.1 \mathrm{mg} / \mathrm{L}(0.8 \mu \mathrm{g} / \mathrm{g}$; Schmitt et al., 2005). Blood $\mathrm{Pb}$ concentrations in most of our samples were $<1.0 \mu \mathrm{g} / \mathrm{g} \mathrm{dw}$, yet statistically significant negative correlations between
ALA-D activity and blood $\mathrm{Pb}$ were evident in all three of the species we investigated (Fig. 1). Collectively, and despite the fact that ALA-D inhibition is not equally sensitive to $\mathrm{Pb}$ in all species (Campana et al., 2003; Schmitt et al., 2005), our findings indicate that the blood $\mathrm{Pb}$ threshold for ALA-D inhibition may be $<1.0 \mu \mathrm{g} / \mathrm{g} \mathrm{dw}$ in many fishes. In humans, ALA-D is polymorphic (e.g., $\mathrm{Hu}$ et al., 2001). Although the existence of multiple ALA-Ds has not been investigated or reported in fish, their occurrence and relative abundance could at least partly explain differences in $\mathrm{Pb}$ sensitivity among species.

The ores of the Viburnum Trend are enriched with a variety of metals, but only $\mathrm{Pb}, \mathrm{Zn}$, and $\mathrm{Cu}$ are recovered commercially in substantial quantities from NLB mines 


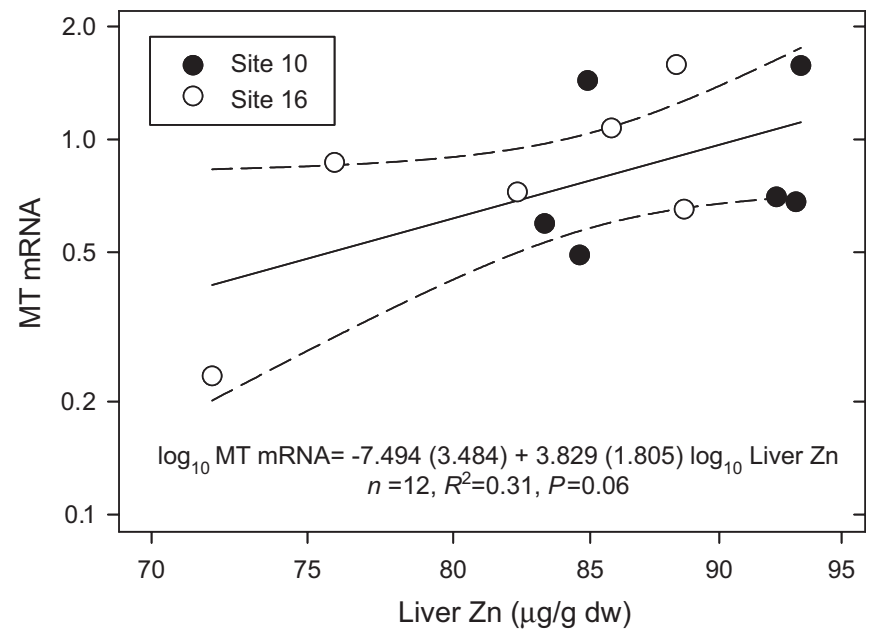

Fig. 4. Metallothionein (MT) rRNA and liver zinc concentrations (Liver $\mathrm{Zn}$; from Schmitt et al., 2007) in stoneroller from two sites. Also shown is the least-squares regression (solid line) and 95\% confidence interval (dashed line) between these variables.

(e.g., Wixson and Jennett, 1975). Small amounts of Co are recovered incidentally (Shedd, 2005), and solid wastes containing $\mathrm{Co}$ and $\mathrm{Ni}$ are generated by the facility on Strother Creek (Doe Run Company, 2003). Although elevated concentrations of these latter metals have not been reported previously in fish from the NLB, Schmitt et al. (2007) detected elevated concentrations of both $\mathrm{Ni}$ and $\mathrm{Co}$ in blood and liver of hog sucker from Site 12 (Strother Creek) relative to Site 11 (Middle Fork at Redmondville, a reference site) and Site 16 (Big River). Concentrations of $\mathrm{Pb}$, $\mathrm{Cd}$, and $\mathrm{Zn}$ were also comparatively high in fish from Site 12 (Schmitt et al., 2007), and ALA-D activity was inhibited in all three species (Table 1); however, $\mathrm{Co}$ and $\mathrm{Ni}$ were not measured in fish from other sites. Nickel toxicity is additive with that of other metals, including $\mathrm{Cd}, \mathrm{Cu}, \mathrm{Pb}$, and $\mathrm{Zn}$ (Enserink et al., 1991), and it can affect heme metabolism. Erythropoiesis and hemoglobin synthesis in fish can be stimulated by Ni (Alkahem, 1994); it can inhibit ALA-D and possibly also ALA synthetase (ALA-S; $\delta$-aminolevulinate synthase, E.C. 2.3.1.37), and can induce heme oxygenase (HO; E.C. 1.14.99.31; Maines, 1980). ALA-S is generally perceived as the rate limiting step in heme synthesis, and $\mathrm{HO}$ catalyzes the degradation of heme to biliverdin (Maines, 1980). Although inspection of the data (Fig. 1) did not indicate that the points representing fish from Site 12 deviated from the overall trend of the blood $\mathrm{Pb}$ :ALA-D relationships, the possible contribution of $\mathrm{Ni}$ to the inhibition of ALA-D at some sites cannot be ruled out as a possible cause of the low apparent blood $\mathrm{Pb}$ thresholds in the species we investigated. However, evaluating the contribution of $\mathrm{Ni}$ would require more data representing a wider range of sites and concentrations.

Cobalt is also an essential element (it is a component of vitamin $\mathrm{B}_{12}$ ) that can be toxic to fish. Although the mechanism of Co toxicity is unknown, it can act as an antagonist with respect to the toxicity of other metals
(Marr et al., 1998). In warm-blooded vertebrates, Co has been shown to stimulate ALA-S and HO (e.g., Maines and Sinclair, 1977; Maines et al., 1976), but its effects on heme homeostatis in fish has not been investigated.

In addition to affecting heme metabolism, $\mathrm{Co}, \mathrm{Cd}$, and $\mathrm{Ni}$ can also inhibit cytochrome P-450 induction in fish (Maines, 1980; Spaethe and Jollow, 1989; Taylor, 1990; Brüschweiler et al., 1996). The cytochrome P-450 enzymes are involved in the detoxification of xenobiotic organic chemicals and the homeostasis of steroid hormones; their inhibition could therefore influence both the toxicity of organic chemicals and reproduction in fish (Stegeman and Hahn, 1994). Sodium cyanide, along with xanthates, alcohols, and other organic chemicals, are used in the milling process (Jennett and Callier, 1977; Wixson, 1978). These and other organic chemicals may interact with metals to affect heme synthesis and metabolism.

Consistent with previous studies, positive terms for blood $\mathrm{Zn}$ were included in some of our statistical models describing ALA-D activity (Table 2). The ameliorative effect of $\mathrm{Zn}$ has been attributed to the fact that it is required as a cofactor for ALA-D, and that $\mathrm{Zn}$ may be able to displace $\mathrm{Pb}$ from the metal binding site of the enzyme (Warren et al., 1998); however, as noted by Schmitt et al. (2002), not all researchers agree on the latter. The lack of a consistent $\mathrm{Zn}$ effect in our data may reflect both differences among species and the comparatively narrow range of blood $\mathrm{Zn}$ concentrations in our fish relative to other studies. In contrast to $\mathrm{Pb}$ and $\mathrm{Cd}, \mathrm{Zn}$ is an essential element; internal concentrations tend to be tightly regulated by fish (Bury et al., 2003). The range of blood $\mathrm{Zn}$ concentrations in our fish was much smaller than that of $\mathrm{Pb}$ and $\mathrm{Cd}$, and differences among groups of sites based on their proximity to NLB mines were not statistically significant (Schmitt et al., 2007).

Prolonged exposure of birds and mammals (including humans) to $\mathrm{Pb}$ ultimately results in anemia. However, and as noted by Schmitt et al. (2002, 2005), such effects have only been inconsistently documented in fish. Some of our fish from Site 16 (Big River) and Site 7 (Sweetwater Creek) with high blood $\mathrm{Pb}$ appeared to be anemic, as indicated by comparatively low $\mathrm{Hb}$ and blood Fe concentrations, but the sample size was small and results were inconsistent; i.e., blood $\mathrm{Fe}$ and $\mathrm{Hb}$ concentrations were also low in some fish with low blood $\mathrm{Pb}$ and vice-versa. In general, our findings support the widely held belief that ALA-D is not a ratelimiting step in heme synthesis by fish, and that most environmental $\mathrm{Pb}$ concentrations are lower than those necessary to produce anemia and other hematological effects as measured by the methods typically employed. Nevertheless, ALA-D is an extremely sensitive indicator of environmental $\mathrm{Pb}$ exposure. In addition, $\mathrm{Hb}$ and $\mathrm{Fe}$ concentrations, as well as other traditional endpoints used to assess fish blood such as cell counts and hematocrit, are relatively crude measurements (Houston, 1997; Schmitt et al., 2002). More sensitive techniques have demonstrated $\mathrm{Cd}$ effects on erythron status in laboratory studies 
(Houston, 1997), but to date no thorough study of $\mathrm{Pb}$ effects on erythropoiesis in fish has been reported.

Comparisons of ALA-D activity among investigations can be difficult due to species differences, differing acclimation temperatures, activity standardization (to $\mathrm{Hb}$, hematocrit, etc.), and assay-related variables ( $\mathrm{pH}$, temperature, etc.; Schmitt et al., 2005). Comparisons are therefore often based on proportional activity relative to reference or control values generated independently within each study. In wildlife, $50 \%$ ALA-D inhibition relative to relevant reference or control activity is considered evidence of injury associated with exposure to environmental $\mathrm{Pb}$ (US Department of the Interior, 1987), a value that has also been used with fish (e.g., Schmitt et al., 2002, 2005). Mean unstandardized ALA-D activity in reference fish (from Sites 3, 10,11 , and 15 ) averaged $1.8 \mathrm{nmol} \mathrm{PBG} / \mathrm{mL} / \mathrm{h}$ in hog sucker, $1.3 \mathrm{nmol} \mathrm{PBG} / \mathrm{mL} / \mathrm{h}$ in sunfish, and $1.0 \mathrm{nmol} \mathrm{PBG} . \mathrm{mL} / \mathrm{h}$ in stoneroller; and ALA-D $/ \mathrm{Hb}$ averaged $3.4 \mathrm{nmol} \mathrm{PBG} / \mathrm{mg} / \mathrm{h}$ in hog sucker, $1.6 \mathrm{nmol} \mathrm{PBG} / \mathrm{mg} / \mathrm{h}$ in sunfish, and $1.1 \mathrm{nmolPBG} / \mathrm{mg} / \mathrm{h}$ in stoneroller (Table 1). Relative to these values, mean ALA-D activity was inhibited by $\geqslant 50 \%$ only in hog sucker from Site 16 (Big River) and stoneroller from Site 13 (Neals Creek; Table 1). Activity was also reduced by $\geqslant 50 \%$ in a few individual sunfish and stoneroller from Site 16 and from some sites $<10 \mathrm{~km}$ downstream from NLB mines (Fig. 1). Mean ALA-D/Hb was not inhibited by $\geqslant 50 \%$ relative to reference sites in any taxa from any site (Table 1); however, some ALA-D/Hb differences were confounded with low $\mathrm{Hb}$ concentrations (Fig. 2; Table 1). Overall, the degree of inhibition evident in the species we evaluated from the Big River and sites near NLB mines were less than what was reported for common carp and bass by Schmitt et al. (2005), which is consistent with the lower blood $\mathrm{Pb}$ concentrations in our fish.

Higher-level biological effects, including but not limited to behavioral changes, have been reported less frequently and associated only indirectly with $\mathrm{Pb}$ exposure and ALA-D inhibition in fish. Inhibition may ultimately result in the accumulation of ALA (Kelada et al., 2001), which is structurally similar to $\gamma$-aminobutyric acid (GABA). The stimulation of GABA receptors in the nervous system by ALA may be a primary mechanism of $\mathrm{Pb}$-induced neurotoxicity (Kelada et al., 2001; Warren et al., 1998). "Black tail", which represents a grossly observable response to $\mathrm{Pb}$-induced neurotoxicity, was associated with blood- $\mathrm{Pb}$ of $1.7 \mathrm{mg} / \mathrm{L}$ (about $13.6 \mu \mathrm{g} / \mathrm{g} \mathrm{dw}$ ) and ALA-D inhibition of $74 \%$ relative to controls in laboratoryexposed rainbow trout (Oncohrynchus mykiss; Hodson et al., 1979). Blood $\mathrm{Pb}$ in our fish did not exceed $7.72 \mu \mathrm{g} /$ $\mathrm{gdw}$ (Fig. 1), but some fish from the Big River analyzed in previous studies did (Schmitt et al., 1984, 1993, 2005). Although black tail has not been reported in wild fish by any scientific investigations, a recent newspaper article reported that it had been observed in fish from the Big River (Rehagen, 2004). Behavioral effects have been induced in fathead minnow exposed to part-per-million concentrations of waterborne $\mathrm{Pb}$ (Weber et al., 1991), in mirror carp (Cyprinus carpio) at $\leqslant 50 \mu \mathrm{g} / \mathrm{L}$ in moderately hard water (Shafiq-ur-Rehman, 2003), and in rainbow trout at $29 \mu \mathrm{g} / \mathrm{L}$ in moderately hard water (Burden et al., 1998); growth and ALA-D activity were also affected at higher concentrations in the rainbow trout, and lipid peroxidation was detected in the brains of the mirror carp. In contrast, neither behavioral nor hematological effects were elicited in smallmouth bass (Micropterus dolomieu) fingerlings exposed to $\leqslant 405 \mu \mathrm{g} / \mathrm{L}$ of $\mathrm{Pb}$ in moderately hard water for $90 \mathrm{~d}$ (Coughlan et al., 1986). Effects on bone strength, which may impair swimming performance and increase vulnerability to predators, were detected in sunfish from the Big River with blood $\mathrm{Pb}$ concentrations of about $0.5 \mathrm{mg} / \mathrm{L}$ (Dwyer et al., 1988). Stippled erythrocytes and spinal deformities have been induced in common carp exposed to part-per-million concentrations of $\mathrm{Pb}$ in the laboratory (Holcombe et al., 1976; Beretić et al., 1980), as have additional sub-lethal effects in other fishes (Johansson-Sjöbeck and Larsson, 1979; Weber et al., 1991). Organism-, population-, and community-level effects were associated with reduced ALA-D activity in two species of catfish (Pimelodidae) inhabiting a tailings-contaminated stream (Moraes et al., 2003). Blood Pb concentrations were not measured in this study, but muscle $\mathrm{Pb}$ concentrations in the two species averaged $2.97 \mu \mathrm{g} / \mathrm{g}$ and $7.55 \mu \mathrm{g} / \mathrm{g} \mathrm{dw}$ $(0.59 \mu \mathrm{g} / \mathrm{g}$ and $1.5 \mu \mathrm{g} / \mathrm{g}$ ww assuming $80 \%$ moisture), which are within the range of recently reported fillet concentrations in fish from the Big River (Gale et al., 2004).

Other than ALA-D, the effects of $\mathrm{Pb}$ and other metals on porphyrin metabolism in fish has received limited study. Theodakoris et al. (1992) reported increased ZPP concentrations in bluegill exposed to $\mathrm{Pb}$-contaminated sediments, with ZPP increasing over $8 \mathrm{wk}$ of exposure. In contrast, Hodson et al. (1984) detected only low levels of porphyrins by scanning fluorometry in blood extracts from rainbow trout exposed to $\mathrm{Pb}$ in the laboratory; ALA-D activity was $>50 \%$ inhibited in these fish, which also showed evidence of neurotoxicity (black tails). We detected ZPP by hematofluorometry in all specimens of three species, including bluegill, in our pilot studies. We also detected ZPP fluorescence in some stoneroller, hog sucker, and sunfish from $\mathrm{Pb}$-contaminated sites, but none in other specimens of the same species with equally high blood $\mathrm{Pb}$ concentrations (Fig. 3). In addition, ZPP concentrations in bluegill and lake sturgeon tended to increase over time in refrigerated samples, which may represent the fluorescence of bilirubin (Buhrmann et al., 1978) or some other substance.

In mammals, ZPP has been shown to be both more (Simmonds et al., 1995) and less (Schuhmacher et al., 1997) sensitive than ALA-D inhibition to Pb. In birds and in the American toad (Bufo arenarum), ferrochelatase inhibition results in the accumulation of free erythrocyte protoporphyrin (FEP), and FEP measurement by hematofluorometry has been used as a biomarker of $\mathrm{Pb}$ exposure (Anderson and Havera, 1985; Arrieta et al., 2004; Blus et al., 1991; Franson et al., 1986; Roscoe et al., 1979). In the American 
toad, FEP is more sensitive to $\mathrm{Pb}$ than ALA-D (Arrieta et al., 2004), but the general consensus among avian toxicologists is that FEP accumulation is less sensitive than ALA-D (Pain, 1989; Beyer et al., 2000). The limited data available (ours and previous studies) indicate that ZPP is also less sensitive than ALA-D in fish, but substantially more data and information on porphyrin biochemistry in fish is needed. A particular shortcoming is the lack of information on possible effects of other metals such as Co and $\mathrm{Ni}$, which have been shown to substitute for $\mathrm{Fe}$ in protoporphyrin IX in mammals (Rosenberg, 1993).

Hepatic lipid peroxidation, as indicated by the measurement of FPLPs, differed by about 3-fold in the two species we analyzed, but no differences related to metals were detected (Table 3). Using similar methods, Farag et al. $(1995,2003)$ detected significantly $(P<0.05)$ greater hepatic lipid peroxidation in brown trout (Salmo trutta) and rainbow trout from mining-contaminated sites on the Clark Fork River and in the Boulder River system of Montana than at reference sites. Liver Cd concentrations averaged about $2.5 \mu \mathrm{g} / \mathrm{g} \mathrm{dw}$ and liver $\mathrm{Pb}$ about $1.0 \mu \mathrm{g} / \mathrm{g} \mathrm{dw}$ in brown trout from the Clark Fork site, which are substantially lower than the concentrations in our stoneroller. Liver $\mathrm{Zn}$ concentrations in the Clark Fork fish were not measured, but they contained elevated concentrations of $\mathrm{Cu}$ and arsenic (Farag et al., 1995). Maximum liver Cd concentrations in our stoneroller and sunfish were substantially lower than those in the rainbow trout from the Boulder River site, which were about $100 \mu \mathrm{g} / \mathrm{gdw}$. Our liver $\mathrm{Zn}$ maxima were somewhat lower than those from the Boulder River (Farag et al., 2003, which were about $200 \mu \mathrm{g} / \mathrm{g} \mathrm{dw}$, but maximum liver $\mathrm{Pb}$ concentrations in our fish of both species selected as "high $\mathrm{Pb}$ " (maxima $3.41-7.79 \mu \mathrm{g} / \mathrm{g} \mathrm{dw}$ ) were substantially greater (maxima $<1.0 \mu \mathrm{g} / \mathrm{g} \mathrm{dw}$; Farag et al., 2003). The Boulder River fish, like those from the Clark Fork, had also been exposed to comparatively high $\mathrm{Cu}$ concentrations (Farag et al., 2003). Collectively, these results indicate that metals other than $\mathrm{Pb}$ caused the lipid peroxidation reported by Farag et al. (1995, 2003).

The results of other investigations also indicate that lipid peroxidation is less sensitive to $\mathrm{Pb}$ than to other metals. In a laboratory study, Campana et al. (2003) detected only small effects on hepatic lipid peroxidation in European (Lusitanian) toadfish (Halobatrachus didactylus) following interperitoneal (ip) injection of $\mathrm{Pb}$ even though liver $\mathrm{Pb}$ concentrations reached $300 \mu \mathrm{g} / \mathrm{g}$ ww $(1429 \mu \mathrm{g} / \mathrm{g} \mathrm{dw}$ assuming 79\% moisture; Harrison and Klaverkamp, 1990). As noted previously, $\mathrm{Pb}$ concentrations in fish from the tailings-contaminated reaches of the Big River are among the greatest on record (e.g., Gale et al., 2004; Schmitt et al., 1984, 1993, 2005, 2007), and a human consumption advisory is in effect (Missouri Department of Health and Senior Services, 2006). Nevertheless, concentrations of other mining-derived metals in fish are greater elsewhere (e.g., Schmitt et al., 1993, 2007; Farag et al., 2003). Copper is among the metals recovered from mines in the NLB
(Wixson and Jennett, 1975; Wixson, 1978), but neither previous nor ongoing studies have reported elevated concentrations in NLB streams (Schmitt et al., 1993; Petersen et al., 1998; Besser et al., 2003). Based on a review of extant literature, Campana et al. (2003) hypothesized that in contrast to $\mathrm{Cu}$, neither $\mathrm{Pb}$ nor $\mathrm{Cd}$ can change their oxidation states, a requirement of the redox cycling necessary for lipid peroxidation. Collectively, these findings indicate that hepatic lipid peroxidation in fish may not be as sensitive to $\mathrm{Pb}$ as ALA-D, but that it may have potential as a biomarker of exposure to other metals in NLB fish.

Hepatic MT mRNA induction, which we measured by RT-PCR, was correlated only with liver Zn. Within-site variation was comparatively high (Fig. 4), and differences among sites were not statistically significant (Table 4). As noted, the range of metal concentrations spanned by the fish and sites selected for these analyses may not have been sufficient for the detection of among-site differences in MT induction, and the sample size was small (Table 4). Campana et al. (2003) detected increased MT protein concentrations in European toadfish $7 \mathrm{~d}$ after interperitoneal injection of $\mathrm{Pb}$, by which time liver $\mathrm{Pb}$ concentrations had plateaued at about $300 \mu \mathrm{g} / \mathrm{g}$ ww $(1429 \mu \mathrm{g} / \mathrm{g} \mathrm{dw}$ assuming $79 \%$ moisture). These concentrations are $>10$-fold higher than liver $\mathrm{Pb}$ concentrations in our fish (Schmitt et al., 2007). Campana et al. (2003) also noted that the time course for induction may be temperature related, and that both the timing and intensity of the MT response may differ among metals. They hypothesized that $\mathrm{Pb}$ was a weak MT inducer relative to other metals because of its comparatively low (compared with other metals) sulfhydryl binding affinity. Farag et al. (1995) reported an increase in hepatic MT protein of about 3-fold relative to reference sites in brown trout from a contaminated site on the Clark Fork, and Farag et al. (2003) detected as much as 30-fold greater MT protein concentrations in the livers of rainbow trout from mining-contaminated streams in the Boulder River system. Given that $\mathrm{Pb}$ is a weak inducer of $\mathrm{MT}$ (Campana et al., 2003), these responses may reflect the comparatively greater concentrations of metals other than $\mathrm{Pb}$ to which the Montana fish had been exposed (Farag et al., 1995, 2003), as also hypothesized for lipid peroxidation. The induction of MT can also be affected by a wide range of factors such as fish age, gender, size, and reproductive status (Lacorn et al., 2001). Although we attempted to standardize fish size, we did not control for these other factors, which probably contributed to the variation in our data (Fig. 4).

Another factor to consider when using MT as a biomarker is the method used to measure it relative to the exposure history of the organisms. Traditional methods typically determine the amount or concentration of MT present in the tissues (e.g., Hogstrand and Haux, 1990; Lacorn et al., 2001; Campana et al., 2003; Farag et al., 2003) or the amount of Cd that can be bound by MT or other proteins (e.g., Hamilton et al., 1987; Cope et al., 1994; Kamman et al., 1997). These methods document the 
cumulative, long-term exposure history of the animals. In contrast, RT-PCR responds to active or recent MT synthesis (Norey et al., 1990). Consequently, MT mRNA might not be detected in resident fish that have acclimated to contemporary exposure conditions. RT-PCR has been used to detect MT induction in caged, un-acclimated fish held in metals-contaminated streams (McClain et al., 2003; Roberts et al., 2005). These findings indicate that RT-PCR might be better suited to use with transplanted, naïve fish, in which extraneous (and potentially confounding) variables such as genetic diversity, exposure/acclimation history, age, reproductive status, nutrition, size, and gender can also be controlled; and that measurement of metallothionein concentrations by traditional methods is better for documenting the long-term exposure of wild fish. Studies incorporating these methods at sites representing a wider range of metals concentrations may ultimately demonstrate both metallothionein and lipid peroxidase differences among NLB sites and stronger concentrationdependent relationships.

As a final consideration, multiple MT isoforms have been documented in fish and other organisms (Klaverkamp et al., 1984; Carginale et al., 1998; Lacorn et al., 2001; Muto et al., 1999), and not all isoforms respond to metals. Lacorn et al. (2001) reported that only one of two MT isoforms in dab (Limanda limanda) was induced by metals, the other by rising temperature. Furthermore, expression of the cDNAs specific to different MT isoforms has been shown to be differentially regulated by exposure to different metals (Carginale et al., 1998; Ren et al., 2000). Lacorn et al. (2001) therefore questioned the use of MT as a biomarker of exposure without first confirming that the isoform being measured responds to metals.

\section{Conclusions}

We documented elevated blood metals concentrations and negative statistical relations between blood $\mathrm{Pb}$ concentrations and ALA-D activity in stoneroller, sunfish, and hog sucker. Greatest $\mathrm{Pb}$ concentrations and lowest ALA-D activity in all three species were in fish from the Big River and at sites $<10 \mathrm{~km}$ downstream from NLB mines. Conversely, lowest $\mathrm{Pb}$ concentrations and greatest ALA-D activity were in fish from reference sites and the exploration area. Consistent with previous findings, and with some exceptions, blood $\mathrm{Pb}$ concentrations in NLB fish exceeded reference concentrations but were lower than those from the Big River and other historical mining areas in the US and elsewhere, as would be expected given the modern technology and environmental regulation of the NLB. Nevertheless, ALA-D activity was inhibited in fish of all species from sites near mines, indicating that $\mathrm{Pb}$ is both bioavailable and biochemically active in streams draining the NLB. It is generally believed that because the conversion of ALA to PBG is not the rate-limiting step in heme synthesis, the inhibition of ALA-D does not by itself lead to anemia. However, we observed limited evidence of anemia (i.e., lower $\mathrm{Hb}$ and blood $\mathrm{Fe}$ concentrations) in some fish from mining-affected sites, which differs from previous findings. As noted by Schmitt et al. (2005), the use of more sensitive indicators (e.g., Houston, 1997) may eventually demonstrate a relationship between ALA-D activity and heme status in fish. In addition, the influence of $\mathrm{Ni}$ and $\mathrm{Co}$ from mining in the NLB on porphyrin metabolism in fish is unknown.

Trends for $\mathrm{Cd}$ and $\mathrm{Zn}$ were less evident than those for $\mathrm{Pb}$. Although greatest concentrations of $\mathrm{Cd}$ and $\mathrm{Zn}$ were in fish from sites $<10 \mathrm{~km}$ downstream from NLB mines, there was considerable variability within and among sites. Brumbaugh et al. (2005) noted similar variability for $\mathrm{Cd}$ and $\mathrm{Zn}$ relative to $\mathrm{Pb}$ in fish from mining areas in Oklahoma, and suggested that these differences reflected differing long-term exposure histories and accumulation patterns. Although liver $\mathrm{Zn}$ and MT induction were correlated, our findings indicate that RT-PCR may not be the best way to document long-term exposure and MT effects. We also failed to detect effects on hepatic lipid peroxidation, which indicates that both MT and hepatic lipid peroxidation are less sensitive to $\mathrm{Pb}$ than to other metals. However, the biomarkers for this study were selected based on the well known effects of $\mathrm{Pb}$ on heme synthesis and of several metals on MT induction and lipid peroxidation. Previous studies in the NLB (i.e., Wixson, 1978; Schmitt et al., 1993; Petersen et al., 1998) had not reported elevated $\mathrm{Ni}$ or Co concentrations, which became evident during the course of our investigation and subsequent studies (Besser et al., 2003; Schmitt et al., 2007). Ongoing studies in the NLB are therefore examining for ecological effects attributable to metals beyond $\mathrm{Pb}, \mathrm{Zn}$, and $\mathrm{Cd}$ (including $\mathrm{Ni}$ and $\mathrm{Co}$ ), at a wider range of sites. Future biomarker studies, if conducted, should incorporate a battery of biomarkers that have been shown to respond to a variety of mining-associated metals. In addition to the endpoints we used, these should include histopathological evaluations to document macrophage aggregate numbers, hyperplasia, and other lesions in the kidney; histopathological lesions in the gill, brain, and liver; and reproductive and developmental biomarkers, including gonadal histopathology (e.g., Farag et al., 1999, 2003; Campana et al., 2003; Pereira et al., 1993). Both caged and wild fish should be studied to document both short- and long-term exposures (e.g., Theodakoris et al., 1992; McClain et al., 2003; Roberts et al., 2005) and the effects of milling reagents should be investigated.

Lastly, it is important to recognize that the environmental effects of mining vary temporally in response to many factors. In addition to natural factors, these include the variable mineral composition of ores, mining intensity changes related to global market forces, and improvements in extraction and effluent treatment technology. Mining intensity in the NLB waned during the 1990s, but elevated concentrations of metals and their effects in fish were nevertheless evident at most sites located near NLB mines. Mining and exploration activity in southern Missouri has 
recently begun to increase in response to rising demand for $\mathrm{Pb}$ and other metals. Continued investigation and monitoring of streams in this region is therefore warranted.

\section{Acknowledgments}

J.A. Allert, J. Arms, W. Brumbaugh, M. Walther, R. Wiedemeyer, D. Hardesty, D. Whites, S. Olson, D. Parris, and J. Besser assisted with fish collections. W. Brumbaugh, J. Arms, D. Nicks, J. Candrl, R. Lipkin, and A. Donahue assisted with fish processing and tissue preservation. W. Brumbaugh, M. Walther, J. Arms, and S. Koppi assisted with metals analyses. P. Ciesclewicz and M. Reed of the Missouri Department of Conservation also assisted with fish collections. The ZPP measurements on preserved erythrocytes were performed at Aviv Instrument, Lakewood, NJ under the supervision of J. Aviv; he also provided advice on hematofluorometry, as did B. Rattner of the USGS Patuxent Wildlife Research Center, Laurel, MD. J. Hoffman of Miami (Ohio) University provided the fathead minnow MT sequence data. A. Farag and B. Mueller of the CERC-Jackson, WY Field Research Station provided guidance on the conduct of the lipid peroxidation assay. E. Little, C. Caldwell, and two anonymous reviewers provided useful comments that were incorporated into this paper. We greatly appreciate the help of the many private landowners who granted us permission to sample on their properties.

\section{Disclaimer}

This study was conducted by the Columbia Environmental Research Center (CERC) of the US Geological Survey (USGS) as part of a Congressionally funded investigation of the effects of mining in the Mark Twain National Forest (Missouri, USA). Fish were collected in accordance with a permit from the Missouri Department of Conservation. All procedures conformed to the "Guidelines for the Use of Fishes in Research" of the American Fisheries Society (AFS), Institute of Fishery Research Biologists (AIFRB), and American Society of Ichthyologists and Herpetologists (ASIH) Use of Fishes in Research Committee (AFS, AIFRB, and ASIH, 2004) and with all USGS and CERC guidelines for the humane treatment of test organisms during culture and experimentation. Use of trade names does not constitute endorsement.

\section{References}

Alkahem, H.F., 1994. The toxicity of nickel and the effects of sublethal levels on haematological parameters and behaviour of the fish, Oreochromis niloticus. J. Univ. Kuwait Sci. 21, 243-252.

American Fisheries Society (AFS), American Institute of Fishery Research Biologists (AIFRV), and American Society of Ichthyologists and Herpetologists (ASIH), 2004. Guidelines for the use of fishes in research. American Fisheries Society, Bethesda, MD, 54 p. 〈http:/ www.fisheries.org/html/Public_Affairs/Sound_Science/Guidelines2004. shtml >.
Anderson, W.L., Havera, S.P., 1985. Blood lead, protoporphyrin, and ingested shot for detecting lead poisoning in waterfowl. Wildl. Soc. Bull. 13, 26-31.

Arrieta, M.A., Bruzzone, L., Apartin, C., Rosenberg, C.E., Fingk, N.E., Salabián, 2004. Biosensors of inorganic lead exposure and effect in an adult amphibian. Arch. Environ. Contam. Toxicol. 46, 224-230.

Aviv Biomedical, Inc., 2001. ZP Hematofluorometer Model 206D Hematofluorometer. Instruction manual. Aviv Biomedical, Lakewood, NJ, 28p.

Beretić, T., Zibar-Śikić, J., Prpić-Majić, D., Tudor, M., 1980. Some morphological and hematological parameters of abnormal lead absorption in fish. In: Branica, M., Zdenka, K. (Eds.), Lead in the Marine Environment. Pergamon Press, Oxford, UK, pp. 263-269.

Besser, J.M., Brumbaugh, W.G., Brunson, E.O., Allert, A.L., Schmitt, C.J., 2003. Metal bioavailability in stream and reservoir sediments from stream and reservoir sites in the vicinity of lead mining areas in Missouri. 24th Annual Meeting of the Society of Environmental Toxicology and Chemistry, November 11-15, Austin, TX.

Beyer, W.N., Audet, D.J., Heinz, G.H., Hoffman, D.J., Day, D., 2000. Relation of waterfowl poisoning to sediment lead concentrations in the Coeur d'Alene River Basin. Ecotoxicology 9, 207-218.

Blus, L.J., Henny, C.J., Hoffman, D.J., Grove, R.A., 1991. Lead toxicosis in tundra swans near a mining and smelting complex in Northern Idaho. Arch. Environ. Contam. Toxicol. 21, 549-555.

Brumbaugh, W.G., Schmitt, C.J., May, T.W., 2005. Concentrations of cadmium, lead, and zinc in fish from mining-influenced waters of Northeastern Oklahoma: sampling of blood, carcass, and liver for aquatic biomonitoring. Arch. Environ. Contam. Toxicol. 49, 76-88.

Brüschweiler, B.J., Würgler, F.E., Fent, K., 1996. Inhibitory effects of heavy metals on cytochrome P450A1 induction in permanent fish hepatoma cells. Arch. Environ. Contam. Toxicol. 31, 475-482.

Buhrmann, E., Menzer, W.C., Lubin, B.H., 1978. The influence of plasma bilirubin on zinc protoporphyrin measurement by a hematofluorimeter. J. Lab. Clin. Med. 91, 710-716.

Burden, V.M., Sandheinrich, M.B., Caldwell, C.A., 1998. Effects of lead on the growth and $\delta$-aminolevulinic acid dehydratase activity of juvenile rainbow trout, Oncorhynchus mykiss. Environ. Pollut. 101, 285-289.

Bury, N.R., Walker, P.A., Glover, C.N., 2003. Nutritive metal uptake in teleost fish. J. Exper. Biol. 206, 11-23.

Campana, O., Sarasquete, C., Blasco, J., 2003. Effect of lead on ALA-D activity, metallothionein levels, and lipid peroxidation in blood, kidney, and liver of the toadfish Halobatrachus didactylus. Ecotoxicol. Environ. Saf. 55, 116-125.

Carginale, V., Scudiero, R., Capasso, C., Capasso, A., Kille, P., Di Prisco, G., Paris, E., 1998. Cadmium-induced differential accumulation of metallothionein isoforms in the Antarctic icefish, which exhibits no basal metallothionein protein but high endogenous rRNA levels. Biochem. J. 332, 475-481.

Chisolm Jr., J.J., Thomas, D.J., Hamill, T.G., 1985. Erythrocyte porphobilinogen synthase activity as an indicator of lead exposure in children. Clin. Chem. 31, 601-605.

Cope, W.G., Wiener, J.G., Atchison, G.J., 1994. Hepatic cadmium, metalbinding proteins and bioaccumulation in bluegills exposed to aqueous cadmium. Environ. Toxicol. Chem. 13, 553-562.

Coughlan, D.J., Gloss, S.P., Kubota, J., 1986. Acute and sub-chronic toxicity of lead to the early life stages of smallmouth bass (Micropterus dolomieui). Water, Air, and Soil Pollut. 28, 265-275.

Dillard, C.J., Tappel, A.L., 1984. Fluorescent damage products of lipid peroxidation. Methods Enzymol. 105, 337-341.

Doe Run Company, 2003. Primary Mining and Smelting Division, 2002 annual report to our community, St. Louis, MO. 〈http://www. doerun.com/uploadfile/2002_Primary.pdf $>$.

Dwyer, F.J., Schmitt, C.J., Finger, S.E., Mehrle, P.M., 1988. Biochemical changes in longear sunfish, Lepomis megalotis, associated with lead, cadmium and zinc from mine tailings. J. Fish. Biol. 33, 307-317. 
Enserink, E.L., Maas-Diepveen, J.L., Van Leeuwen, C.J., 1991. Combined effects of metals: an ecotoxicological evaluation. Water Res. 25, 679-687.

Farag, A.M., Skaar, D., Nimick, D.A., MacConnell, E., Hogstrand, C., 2003. Characterizing aquatic health using salmonid mortality, physiology, and biomass estimates in streams with elevated concentrations of arsenic, cadmium, copper, lead, and zinc in the Boulder River watershed, Montana. Trans. Am. Fish. Soc. 132, 450-467.

Farag, A.M., Stansbury, M.A., Hogstrand, C., MacConnell, E., Bergman, H.L., 1995. The physiological impairment of free-ranging brown trout exposed to metals in the Clark Fork River, Montana. Can. J. Fish. Aquat. Sci. 52, 2038-2050.

Farag, A.M., Woodward, D.F., Brumbaugh, W.G., Goldstein, J.N., MacConnell, E., Hogstrand, C., Barrows, F.T., 1999. Dietary effects of metals-contaminated invertebrates from the Coeur d'Alene River, Idaho, on cutthroat trout. Trans. Am. Fish. Soc. 128, 578-592.

Franson, J.C., Haramis, G.M., Perry, M.C., Moore, J.F., 1986. Blood protoporphyrin for detecting lead exposure in canvasbacks. In: Feirabend, J.S., Russell, A.B. (Eds.), Lead Poisoning in Wild Waterfowl - a Workshop. National Wildlife Federation, Washington, DC, pp. 32-37.

Gale, N., Adams, C.D., Wixson, B.F., Loftin, K.A., Huang, Y.-W., 2004. Lead, zinc, copper, and cadmium in fish from and sediments from the Big River and Flat River Creek of Missouri's Old Lead Belt. Environ. Geochem. Health 26, 37-49.

Goldstein, D.H., Kneip, T.J., Rulon, V.P., Cohen, N., 1975. Erythrocytic aminolevulinic acid dehydratase (ALA-D) activity as a biologic parameter for determining exposures to lead. J. Occup. Med. 17, $157-162$.

Grujic-Injac, B., Braunitzer, G., Stangl, A., 1980. Hemoglobins, XXXV: the sequence of the beta A- and beta B- chains of the hemoglobins of the carp (Cyprinius carpio L). Hoppe Seylers Physiol. Chem. 361, $1629-1639$.

Gurer-Orhan, H., Sabir, H.U., Ozgunes, H., 2004. Correlation between clinical indicators of lead poisoning and oxidative stress parameters in controls and lead-exposed workers. Toxicology 195, 147-154.

Hamilton, S.J., Mehrle, P.M., Jones, J.R., 1987. Cadmium-saturation technique for measuring metallothionein in brook trout. Trans. Am. Fish. Soc. 116, 541-550.

Harrison, S.E., Klaverkamp, J.F., 1990. Metal contamination in liver and muscle of northern pike (Esox lucius) and white sucker (Catostomus commersoni) and in sediments from lakes near the smelter at Flin Flon, Manitoba. Environ. Toxicol. Chem. 9, 941-956.

Hodson, P.V., 1976. $\delta$-Aminolevulinic acid dehydratase activity of fish blood as an indicator of a harmful exposure to lead. J. Fish. Res. Board. Can. 33, 268-271.

Hodson, P.V., Blunt, B.R., Jensen, D., Morgan, S., 1979. Effect of fish age on predicted and observed chronic toxicity of lead to rainbow trout in Lake Ontario Water. J. Great Lakes Res. 5, 84-89.

Hodson, P.V., Blunt, B.R., Whittle, D.R., 1984. Monitoring lead exposure in fish. In: Cairns, V.W., Hodson, P.V., Nriagu, J.O. (Eds.), Contaminant Effects on Fisheries. Wiley, New York, pp. 87-98.

Hogstrand, C., Haux, C., 1990. A radioimmunoassay for perch (Perca fluviatilis) metallothionein. Toxicol. Appl. Pharmacol. 103, 56-65.

Holcombe, G.W., Benoit, D.A., Leonard, E.N., McKim, J.M., 1976. Long-term effects of lead exposure on three generations of brook trout (Salvelinus fontinalis). J. Fish. Res. Board Can. 33, 1731-1741.

Houston, A.H., 1997. Review: are the classical hematological variables acceptable indicators of fish health? Trans. Am. Fish. Soc. 126, 879-894.

Hu, H., Wu, T.-T., Cheng, Y., Sparrow, D., Weiss, S., Kelsey, K., 2001. The $\delta$-aminolevulinic acid dehydratase (ALAD) polymorphism and bone and blood lead levels in community-exposed men: the normative aging study. Environ. Health Perspec. 109, 827-832.

Imes, J.L., 2002. Geohydrological and biological investigations associated with a new lead-zinc exploration area near Winona, Missouri, and the Viburnum Trend of southeastern Missouri. Fact Sheet FS 0005-02, US Geological Survey.
Jennett, J.C., Callier, A.J., 1977. Trace organic emissions from lead mining-milling operations. J. Water Pollut. Contr. Fed. 49, 469-488.

Johansson-Sjöbeck, M.-L., Larsson, A., 1979. Effects of inorganic lead on delta-aminolevulinic acid dehydratase activity and hematological variables in the rainbow trout, Salmo gairdneri. Arch. Environ. Contam. Toxicol. 8, 419-431.

Joselow, M.M., 1980. Blood zinc and lead poisoning. In: Nriagu, J.O. (Ed.), Zinc in the Environment, Part II, Health Effects. Wiley, New York, pp. 171-181.

Kamman, U., Brymlas, J., Hein, W., Steinhart, H., 1997. Metal-binding proteins in the bream (Abramis brama L) caught in the River Elbe. Biomarkers 2, 125-129.

Kägi, J.H., Schäffer, A., 1988. Biochemistry of metallothionein. Biochemistry $27,8509-8515$.

Keith, L.H., Crummett, W., Deegan, J., Libby, R.A., Taylor, J.K., Wentler, G., 1983. Principles of environmental analysis. Anal. Chem. 55, 2210-2218.

Kelada, S.N., Shelton, E., Kaufmann, R.B., Khoury, M.J., 2001. Deltaaminolevulinic acid dehydratase genotype and lead toxicity: a HUGE review. Am. J. Epidemiol. 154, 1-13.

Klaverkamp, J.F., Macdonald, W.A., Duncan, D.A., Wageman, R., 1984. Metallothionein and acclimation to heavy metals in fish: a review. In: Cairns, V.W., Hodson, P.V., Nriagu, J.O. (Eds.), Contaminant Effects on Fisheries. Wiley, New York, pp. 99-113.

Labbé, R.F., Vreman, H.J., Stevenson, D.K., 1999. Zinc protoporphyrin: a metabolite with a mission. Clin. Chem. 45, 2060-2072.

Lacorn, M., Lahrssen, A., Rotzoll, N., Simat, T.J., Steinhart, H., 2001. Quantification of metallothionein isoforms in fish liver and its implications for biomonitoring. Environ. Toxicol. Chem. 20, $140-145$.

Lee, S.S., Lee, B.K., Lee, G.S., Stewart, W.F., Simon, D., Kelsey, K., Todd, A.C., Schwartz, B.S., 2001. Associations of lead biomarkers and delta-aminolevulinic acid dehydratase and vitamin D receptor genotypes with hematopoietic outcomes in Korean lead workers. Scand. J. Work Environ. Health 27, 402-411.

Maines, M.D., 1980. Nickel alterations of heme biosynthesis and degradation: implications for the oxidative metabolism of drugs and carcinogens. In: Nriagu, J.O. (Ed.), Nickel in the Environment. Wiley, New York, pp. 547-583.

Maines, M.D., Sinclair, P., 1977. Cobalt regulation of heme synthesis and degradation in avian embryo liver cell culture. J. Biol. Chem. 10, 219-223.

Maines, M.D., Janousěk, V., Tomio, J.M., Kappas, A., 1976. Cobalt inhibition and induction of $\delta$-aminolevulinate synthase in liver. Proc. Natl. Acad. Sci. US 73, 1499-1503.

Marr, J.C.A., Hansen, J.A., Meyer, J.S., Cacela, D., Podrabsky, T., Lipton, J., Bergman, H.L., 1998. Toxicity of cobalt and copper to rainbow trout: application of a mechanistic model for predicting survival. Aquatic Toxicol. 43, 225-238.

McClain, J.S., Oris, J.T., Burton Jr., G.A., Lattier, D., 2003. Laboratory and field validation of multiple molecular biomarkers of contaminant exposure in rainbow trout (Oncohrynchus mykiss). Environ. Toxicol. Chem. 22, 361-370.

Mezzetti, A., Guglielmi, M.D., Pierdomenico, S.D., Costantini, F., Cipollone, F., De Cesare, D., Bucciarelli, T., Ucchino, S., Chiarelli, F., Cuccurullo, F., Romano, F., 1999. Increased systemic oxidative stress after elective endarterectomy: relation to vascular healing and remodeling. Arterioscler. Thromb. Vasc. Biol. 19, 2659-2665.

Missouri Department of Health and Senior Services, 2006. 2006 Fish advisory. Jefferson City, MO, 9pp. 〈http://www.dhss.state.mo.us/ NewsAndPublicNotices/05FishAdvisory.pdf $\rangle$.

Moraes, M., Gerhald, P., Andersson, L., Shimada, H., Sturve, J., Rauch, S., Molander, S., 2003. Establishing causality between exposure to metals and effects on fish. Human Ecol. Risk Assess. 9, 149-169.

Muto, N., Ren, H.-W., Hwang, G.-S., Tominga, S., Itoh, N., Tanaka, K., 1999. Induction of two major isoforms of metallothioneing in crucian carp (Carassius cuvieri) by air-pumping stress, dexamethasone, and metals. Comp. Biochem. Physiol. 122C, 75-82. 
Norey, C.G., Cryer, A., Kay, J., 1990. Induction of metallothionein gene expression by cadmium and the retention of the toxic metal in the tissues of rainbow trout (Salmo gairdneri). Comp. Biochem. Physiol. 97C, 215-220.

Pain, D.J., 1989. Hematological parameters as predictors of blood lead and indicators of lead poisoning in the black duck (Anas rubripes). Environ. Pollut. 60, 67-81.

Pereira, J.J., Mercaldo-Allen, R., Kuropat, C., Luedke, D., Sennefeleder, G., 1993. Effects of cadmium accumulation on serum vitellogenin levels and hepatosomatic and gonadosomatic indices of winter flounder (Pseudopleuronectes americanus). Arch. Environ. Contam. Toxicol. 24, 427-431.

Petersen, J., Adamski, J.C., Bell, R.W., Davis, J.V., Femmer, S.R., Freiwald, D.A., Joseph, R.L., 1998. Water quality in the Ozark Plateaus, Arkansas, Kansas, Missouri, and Oklahoma, 1992-1995. Circular 1158, US Geological Survey, 33pp.

Rehagen, T., 2004. Repairing a river in lead country. Southeast Missourian, Cape Girardeau, MO, September 19. 〈http://www.semissourian.com/ story/print/146417.html $>$.

Ren, H.W., Itoh, N., Kanekiyo, M., Tominaga, S., Kohroki, J., Hwang, G.S., Nakanishi, T., Muto, N., Tanaka, K., 2000. Two metallothioneins in the fresh-water fish, crucian carp (Carassius cuvieri): cDNA cloning and assignment of their expression isoforms. Biol. Pharm. Bull. 23, 145-148.

Roberts, A.P., Oris, J.T., 2004. Multiple biomarker response in rainbow trout following exposure to hexavalent chromium. Comp. Biochem. Physiol. 138C, 221-228.

Roberts, A.P., Oris, J.T., Burton Jr., G.A., Clements, W.H., 2005. Gene expression in caged fish as a first-tier indicator of contaminant exposure in streams. Environ. Toxicol. Chem. 24, 3092-3098.

Rosenberg, D.W., 1993. Pharmacokinetics of cobalt chloride and cobaltprotoporhyrin. Drug Metab. Disp. 21, 846-849.

Ricker, W.E., 1973. Linear regressions in fishery research. J. Fish. Res. Bd. Can. 30, 409-434.

Roscoe, D.E., Nielsen, S.W., Lamola, A.A., Zuckerman, D., 1979. A simple, quantitative test for erythrocyte protoporphyrin in lead-poisoned ducks. J. Wildl. Dis. 15, 127-136.

Sakai, T., 2000. Biomarkers of lead exposure. Ind. Health 38, 127-142.

Schmitt, C.J., Brumbaugh, W.G., May, T.W., 2007. Accumulation of metals in fish from lead-zinc mining areas of southeastern Missouri, USA. Ecotoxicol. Environ. Saf. (in press).

Schmitt, C.J., Caldwell, C.A., Olsen, B., Serdar, D., Coffey, M., 2002. Inhibition of erythrocyte $\delta$-aminolevulinc acid dehydratase (ALAD) activity in fish from waters affected by smelters. Environ. Monit. Assess. 77, 99-119.

Schmitt, C.J., Dwyer, F.J., Finger, S.E., 1984. Bioavailability of Pb and $\mathrm{Zn}$ from mine tailings by erythrocyte $\delta$-aminolevulinic acid dehydratase (ALA-D) activity in suckers (Pisces: Catastomidae). Can. J. Fish. Aquat. Sci. 41, 1030-1040.

Schmitt, C.J., Whyte, J.J., Brumbaugh, W.G., Tillitt, D.E., 2005. Biochemical effects of lead, zinc, and cadmium in the Tri-States district of northeastern Oklahoma, USA. Environ. Toxicol. Chem. 24, 1483-1495.
Schmitt, C.J., Wildhaber, M.L., Hunn, J.B., Nash, T., Tieger, M.N., Steadman, B.L., 1993. Biomonitoring of lead-contaminated Missouri streams with an assay for erythrocyte $\delta$-aminolevulinic acid dehydratase (ALA-D) activity in fish blood. Arch. Environ. Contam. Toxicol. 25, 464-475.

Schuhmacher, M., Paternain, J.L., Domingo, J.L., Corbella, J., 1997. An assessment of some biomonitors indicative of occupational exposure to lead. Trace Elements Electrolytes 14, 145-149.

Shafiq-ur-Rehman, 2003. Lead-exposed increase in movement behaviour and brain lipid peroxidation in fish. J. Environ. Sci. Health 38A, 631-643.

Shedd, K.B., 2005. Cobalt. In: Metals and minerals: US Geological Survey Minerals Yearbook 2003. Vol. I, pp. 19.1-19.16.

Simmonds, P.L., Luckhurst, C.L., Woods, J.S., 1995. Quantitative evaluation of heme biosynthetic pathway parameters as biomarkers of low-level lead exposure in rats. J. Toxicol. Environ. Health 44, 351-367.

Spaethe, S.M., Jollow, D.J., 1989. Effect of cobalt protoporphyrin on hepatic drug-metabolizing enzymes. Specificity for cytochrome P-450. Biochem. Pharmacol. 38, 2027-2038.

Stegeman, J.J., Hahn, M.E., 1994. Biochemistry and molecular biology of monooxygenases: Current directions in forms, functions, and regulation of cytochrome P450 in aquatic species. In: Malins, D.C., Ostrander, G.K. (Eds.), Aquatic Toxicology: Molecular, Biochemical and Cellular Perspectives. CRC/Lewis Press, Boca Raton, FL, pp. 87-206.

Taylor, A., 1990. Cobalt carcinogenesis. In: Foulkes, E.C. (Ed.), Biological Effects of Heavy Metals, Volume II, Metal Carcinogenisis. CRC Press, Boca Raton, FL, pp. 159-172.

Theodakoris, C.W., D’Surney, S.J., Bickham, J.W., Lyne, T.B., Bradley, B.P., Hawkins, W.E., Furkas, W.L., McCarthy, J.F., Shugart, L.R., 1992. Sequential expression of biomarkers in bluegill sunfish exposed contaminated sediment. Ecotoxicology 1, 45-73.

Tom, M., Chen, N., Segev, M., Herut, B., Rinkevich, B., 2004. Quantifying fish metallothionein transcript by real time PCR for its utilization as an environmental biomarker. Mar. Pollut. Bull. 48, 705-710.

US Department of the Interior, 1987. Type B Technical Information Document: Injury to Fish and Wildlife Species. CERCLA 301 Project, Washington, DC, USA

Warren, M.J., Cooper, J.B., Wood, S.P., Shoolingin-Jordan, P.M., 1998. Lead poisoning, haem synthesis and 5-aminolaevulinic acid dehydratase. Trends Biochem. Sci. 23, 217-221.

Weber, D.N., Russo, A., Seale, D.B., R.E. Spieler, R.E., 1991. Waterborne lead affects feeding abilities and neurotransmitter levels of juvenile fathead minnow Pimephales promelas. Aquat. Toxicol. 21, $71-80$.

Wixson, B.G., 1978. Biogeochemical cycling of led in the New Lead Belt of Missouri. In: Nriagu, J.O. (Ed.), The Biogeochemical Cycling of Lead in the Environment, Part A. Ecological Cycles. Elsevier/North Holland Biomedical Press, Amsterdam, pp. 119-136.

Wixson, B.G., Jennett, J.C., 1975. The new lead belt in the forested Ozarks of Missouri. Environ. Sci. Technol. 9, 1128-1133. 